\title{
1. Environmental and Indigenous issues associated with natural gas development in British Columbia
}

\author{
Anna Vypovska, Laura Johnson, \\ Dinara Millington and Allan Fogwill
}

\section{INTRODUCTION}

Currently, the Province of British Columbia (BC) is the second largest producer of marketable natural gas amongst the Canadian provinces, with the most economically viable natural gas wells, both vertical and horizontal (BC OGC 2015a; CAPP 2016). The estimated reserves in the Province at the end of 2014 were 51000 billion (a thousand million) cubic feet (Bcf) of raw natural gas (BC OGC 2015a). Since 2013 approximately 65 percent of the wells drilled in $\mathrm{BC}$ have been in its unconventional Montney Formation, with the remainder of split fairly evenly between the rest of the Province's formations (CERI 2016). As shale gas has increased North American supply of natural gas, investor focus is moving to exports, specifically of liquefied natural gas (LNG). In 2012 the Province issued a Natural Gas Strategy which recognizes natural gas, particularly LNG exports, as a provincial priority and lists a series of actions the Province will undertake to promote the industry (BC MEM 2012). Since 201220 LNG projects have been proposed in $\mathrm{BC}, 18$ export licenses have been issued by the National Energy Board (NEB) and nine environmental assessments (EAs) have been completed by the BC Environmental Assessment Office (BC EAO) and the Canadian Environmental Assessment Agency (CEA Agency), with a few more underway (Province of BC 2016a).

Notwithstanding the fact that natural gas is the world's cleanest burning fossil fuel, potential adverse environmental impacts associated with the natural gas development in $\mathrm{BC}$ are being debated by stakeholders, Indigenous groups and the general public. Potential impacts of the natural gas and LNG projects in BC on Indigenous peoples' interests have been another concern of critical importance, since the Province is characterized by the greatest diversity of Indigenous population in Canada and presents a unique landscape of Aboriginal rights and interests.

This chapter* examines major environmental and Indigenous peoples' 


\section{Handbook of energy politics}

issues facing development of the natural gas and LNG industry in BC and provides examples of the key approaches to mitigate, manage and monitor the issues effectively. It focuses on the following areas:

- Understanding the current legal framework and regulatory requirements associated with the environmental assessment process for natural gas and LNG activities in BC.

- Analyzing the most important environmental issues associated with the development and operation of natural gas pipelines and LNG facilities in BC.

- Defining Indigenous rights and legal issues as they affect natural gas development in $\mathrm{BC}$ and understanding the context of how Indigenous peoples are affected by natural gas and LNG development.

- Providing suggestions on key approaches to address the identified environmental and Indigenous peoples issues and best practices for proponents of natural gas pipelines and LNG projects.

\section{BASELINE INVENTORY OF ENVIRONMENTAL ASSESSMENT APPLICATIONS FOR MAJOR NATURAL GAS AND LNG PROJECTS IN BC}

A discussion of existing and proposed natural gas and LNG projects within the region is fundamental to the analysis of the current state of this industry in British Columbia. We reviewed EA applications and assessment reports for 29 major natural gas, natural gas liquids (NGLs) and LNG projects in BC (including upstream, midstream and downstream developments) that have undergone a typical EA process (active and/or complete) with the provincial (BC EAO) or the federal (CEA Agency or NEB) responsible authority since 2010. Main regulatory requirements to the provincial and federal EA processes for natural gas and LNG projects are briefly outlined in Box 1.1. Detailed information regarding the 29 reviewed projects is presented in Table 1.1 .

The projects selected for this relevant and representative sample of the past, present and anticipated future natural gas projects included those that have entered the EA process (pre-application stage); the projects currently under review with the regulatory authorities; and the projects with an EAC, CPCN or EADS (see Box 1.1) issued, amended or extended since 1 January 2010.

Analysis of the information presented in Table 1.1 by the project type shows that natural gas pipelines and LNG facilities constitute the 


\section{BOX 1.1 REGULATORY REQUIREMENTS TO THE ENVIRONMENTAL ASSESSMENT PROCESS FOR NATURAL GAS AND LNG PROJECTS IN BRITISH COLUMBIA}

Environmental assessments at the provincial level, and often at the federal level as well, are typically required for all major natural gas pipeline and LNG projects developed in $\mathrm{BC}$, in order to determine whether proposed projects should proceed and what are the terms and conditions for their approval (BC EAO 2015a).

A legal framework for provincial $E A s$ includes three major sources: the $B C$ Environmental Assessment Act, 2002 (BC EAA 2002) as the primary EA legislation; regulations under the $\mathrm{BC} E A A$; and common law regarding Indigenous peoples' consultation (BC EAO 2015a). All natural gas pipeline and LNG projects that are considered as "reviewable" under the BC EAA Reviewable Projects Regulation (Province of $B C 2002$ ) are subject to the provincial EA process, with BC $\mathrm{EAO}$ as the main regulator and the provincial responsible authority. BC EAO also enforces compliance with the conditions of provincial Environmental Assessment Certificates (EACs) issued by two ministers responsible for the decision-making for a project undergoing a provincial EA (BC EAO 2015a, 2016a).

Projects that do not require an EA under the BC EAA (for example, seismic exploration, well production, well drilling and well testing projects) may still require other permits or approvals. The majority of provincial permits are provided through the BC Oil and Gas Commission (BC OGC), the primary operational regulator of oil and gas activities in the Province acting under the BC Oil and Gas Activities Act (BC OGC 2015c).

A federal EA may be required for a proposed natural gas pipeline or an LNG facility that meets the thresholds set out in the Regulations Designating Physical Activities (Canada 2012) under the Canadian Environmental Assessment Act, 2012 (CEAA 2012). The CEAA 2012 provides the framework for the federal EA process, with the CEA Agency as the main regulator for intra-provincial pipelines and related facilities and the NEB as the regulator for pipelines that cross provincial and international boundaries (CEAA 2016a). Authorization or approval from the NEB is also required for the export of NGLs and export or import of natural gas (Government of Canada and NEB 2016).

When the CEA Agency is the responsible authority, the federal Minister of the Environment issues an Environmental Assessment Decision Statement (EADS) that concludes whether the proposed project is likely to cause significant adverse environmental effects. If this is the case, the Governor in Council (GIC) has to determine whether the significant adverse environmental effects are justified in the circumstances (CEAA 2016a). When the NEB is the responsible authority, it makes recommendations to the GIC on whether the reviewed project meets a threshold for public convenience and necessity. The GIC is responsible for the decision on whether to issue a Certificate of Public Convenience and Necessity (CPCN) or not, and this decision takes the form of an order to be implemented by the NEB (Government of Canada and NEB 2016).

Federal and provincial EA regulatory processes can overlap due to their nature. In 2004 the federal and provincial governments signed the Agreement on Environmental 
Assessment Cooperation, and later in 2013 BC EAO and the CEA Agency signed a Memorandum of Understanding (MOU) on the Substitution of Environmental Assessments to help facilitate a single review process (BC EAO 2013a). Under substitution, where both federal and provincial EAs are required, there can be a single EA that meets both provincial and federal standards, and a single provincial review process conducted by $\mathrm{BC} E A O$, with two decisions - federal and provincial (BC EAO 2015c; McCarthy Tétrault LLP 2016).

A substitution process differs from equivalency. Under the equivalency provisions of the CEAA 2012, only a single provincial EA is conducted and a single provincial decision is made about whether the proposed project should be granted approval; no federal approval is required. Substitution and equivalency provisions do not apply if a project is being assessed by the NEB or if the project has been referred to a review panel (BC EAO 2015c).

In 2016 the Federal Government launched an interim approach to review major projects under federal EA processes, five main principles of which include: 1) reviewing projects within the current legislative framework and treaty provisions; 2) making decisions based on science and traditional knowledge of Indigenous peoples; 3 ) considering the views of the public and affected communities; 4) meaningful consulting with Indigenous peoples and 5) assessing direct and upstream greenhouse gas (GHG) emissions linked to the proposed projects (Government of Canada 2016a).

two largest categories of the reviewed projects (which include 12 and eight projects, correspondingly). Other categories include natural gas processing facilities (five projects), NGL facilities (two projects), NGL pipelines (one project) and LNG transportation (one project).

As shown in Table 1.1, the reviewed projects involve a wide range of output capacities, with the projected average daily production 0.15 $0.40 \mathrm{Bcfpd}$ for natural gas processing facilities, 0.23-2.2 Bcfpd for natural gas pipelines, and $0.32-3.47 \mathrm{Bcfpd}$ for LNG facilities. The anticipated daily productions of these projects at full build-out range are even higher, up to $0.6 \mathrm{Bcfpd}$ for natural gas processing facilities (Fortune Creek Gas project), up to $8.4 \mathrm{Bcfpd}$ for natural gas pipelines (Westcoast Connector Gas Transmission project) and up to $4.0 \mathrm{Bcfpd}$ for LNG facilities (WCC LNG project).

Analysis of the reviewed EA applications by the provincial EA status demonstrates that for the 12 projects the EA process was completed (that is, an EAC was issued, amended or extended); nine projects are currently at the pre-application stage with $\mathrm{BC}$ EAO; and for the remaining applications, a provincial EAC is not required either due to an equivalency process with the federal regulatory agency (five projects) or because an exemption from obtaining the EAC was granted by BC EAO (three projects).

Distribution of the reviewed EA applications by the federal EA status, 


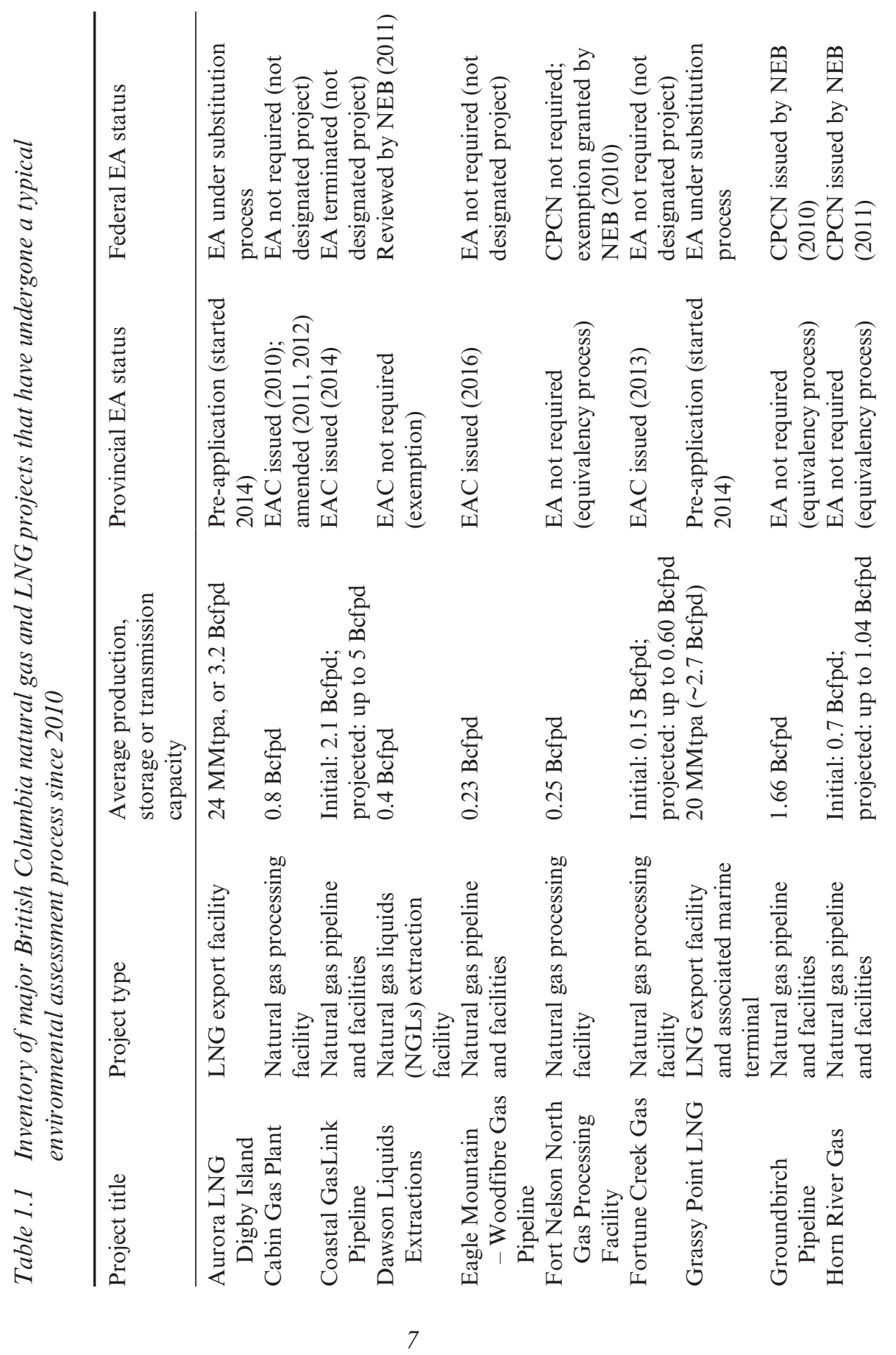




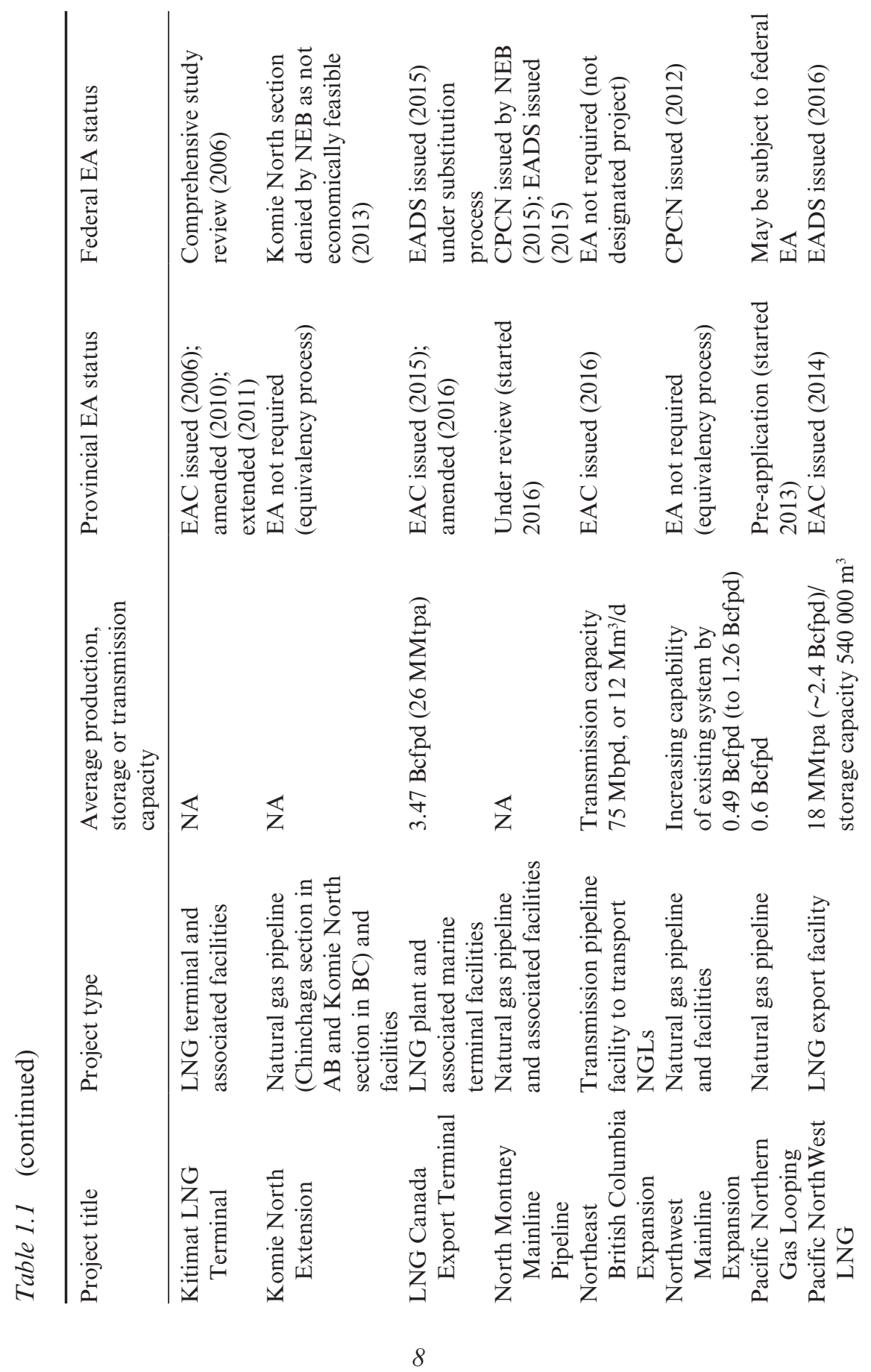




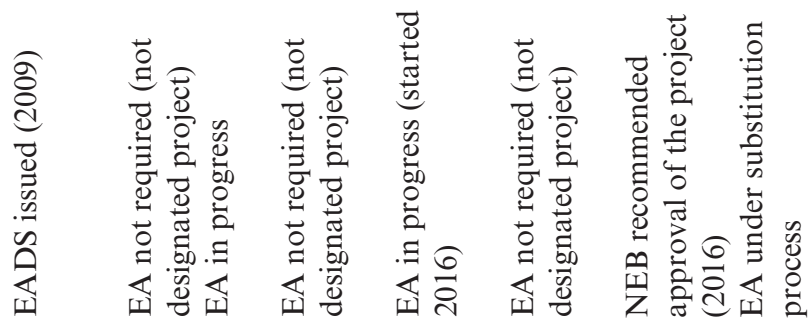

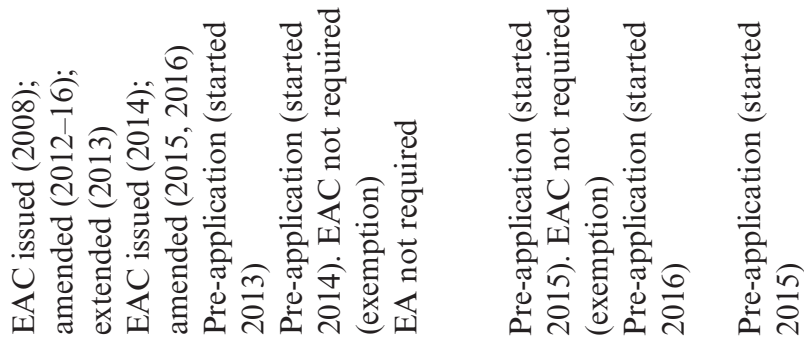

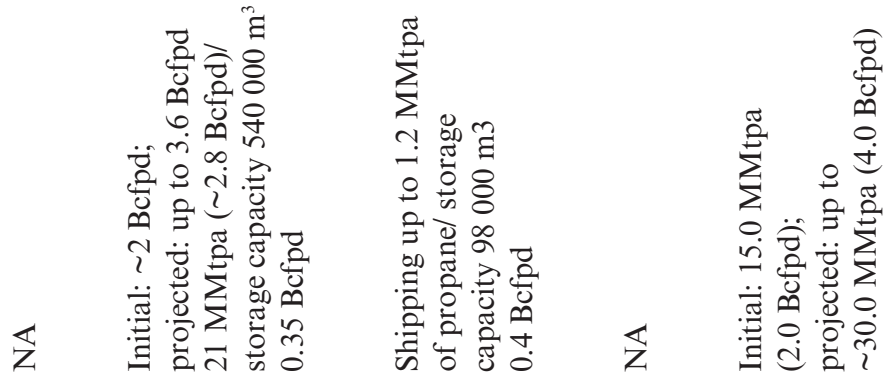

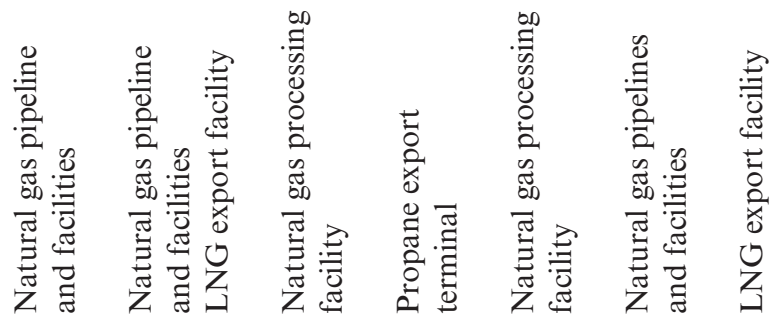

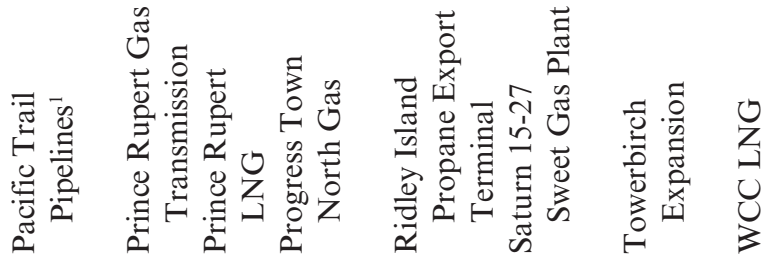




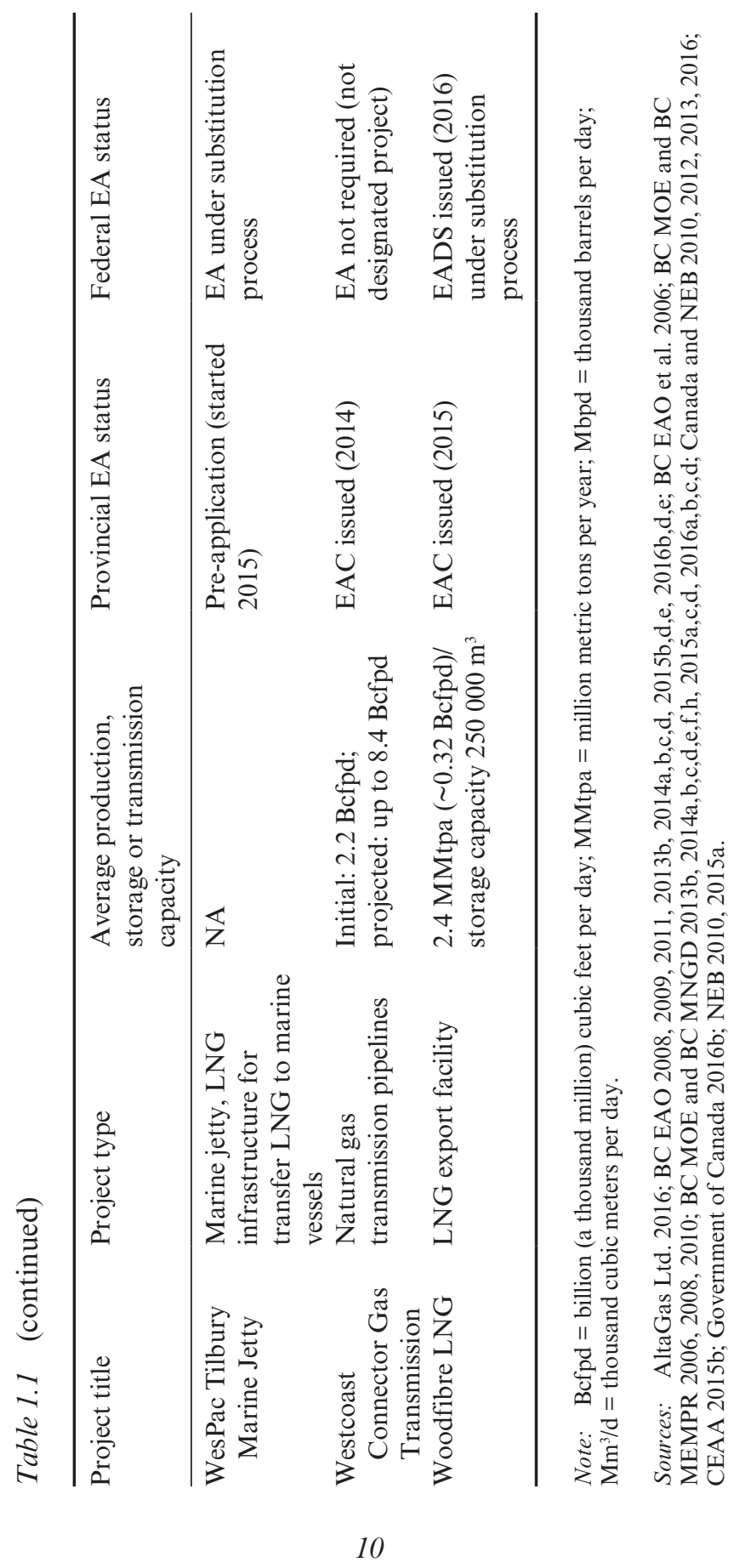


as presented in Table 1.1, shows there are 12 projects with the completed EA process (a CPCN or an EADS issued or denied); three projects with the federal EA process currently underway; and four projects where the federal EA will be conducted under a substitution process with the provincial regulator. For the remaining EA applications, a federal approval is not required either because the projects do not trigger a federal review under the CEAA 2012 (nine projects) or because an exemption from obtaining the CPCN was granted by the NEB (one project).

\section{MAJOR ENVIRONMENTAL ISSUES ASSOCIATED WITH NATURAL GAS AND LNG DEVELOPMENT IN BC}

The key potential environmental issues discussed in this section were selected based on the typical content of EA documents for natural gas pipeline and $\mathrm{LNG}$ projects which is determined by the practice of EA assessment in BC (see Box 1.2 for details). Table 1.2 includes a list of terrestrial and marine valued components (VCs) that may be impacted by the project, with potential effects on these VCs that may result from the construction, operation and/or decommissioning of the proposed projects, as identified by the proponents. Potential adverse effects on the terrestrial VCs were identified from the review of EA applications for all 29 natural gas pipeline and LNG projects that have entered a typical EA process with the provincial and/or federal responsible authority since 2010, as summarized in Table 1.1. Potential adverse effects on the marine VCs were mostly identified on the proposed LNG projects, as well as on a few natural gas pipeline projects that include a marine portion of the pipeline route. In total, the potential of the project to impact marine VCs was discussed by the proponents in 12 out of the 29 reviewed EA applications.

Since the EA process for a number of the reviewed projects has not been completed yet, and therefore, corresponding EA reports from the regulators were not available, other documents submitted by the proponent (including Application Information Requirements or Valued Components Selection documents) have been considered for this analysis. It is important to remember that the adverse effects presented in Table 1.2 are potential interactions between the project activities and the VCs before implementation of mitigation, and they do not necessarily result in residual adverse effects remaining after the implementation of all mitigation measures.

Residual adverse effects on environmental VCs identified by the proponents in the EA applications for the proposed projects were 


\section{BOX 1.2 THE PRACTICE OF ENVIRONMENTAL ASSESSMENT IN BRITISH COLUMBIA}

The provincial EA process consists of three stages: 1) pre-application, where a project description is reviewed; scope, procedures and methods for the EA process are specified; an application for an EAC is submitted by the proponent and evaluated by BC EAO for completeness; 2) application review by the working group composed of representatives of various government agencies and Indigenous groups, with public input provided, where an assessment report is prepared by BC EAO and 3) EAC decision stage, where the responsible Ministers make a decision as to whether to certify the project based on the recommendations from $\mathrm{BC} E A O$ (BC EAO 2016a).

The federal EA process is conducted within the framework provided by the CEAA 2012 and is focused on assessing potential adverse environmental effects that are within federal jurisdiction, including fish and fish habitat, other aquatic species, migratory birds, federal lands, effects that cross provincial or international boundaries and impacts on Indigenous peoples (CEAA 2016a; McCarthy Tétrault LLP 2016).

An EA application is typically organized around the valued components (VCs) which the project has the potential to impact. For the purposes of the EA process in British Columbia, valued components are defined as "aspects of the natural and human environment that are considered to have scientific, ecological, economic, social, cultural, archaeological, historical or other importance" (BC EAO 2015a). VCs represent the foundation of environmental assessments in British Columbia and many other jurisdictions as well. Selected VCs will vary for each project depending on the characteristics of the project and the region and context within which it is located and should be identified as early in the assessment process as possible (BC EAO 2013d).

The EA application typically includes the proponent's baseline data of the study areas, as well as the analysis of the potential environmental, social, health, heritage and economic effects of the project on the selected VCs. The application must describe the technically and economically feasible mitigation measures to prevent or reduce to an acceptable level any potential adverse effects of the project on selected VCs (BC EAO 2013d, 2015a). A critical step in the EA process is to determine if the residual adverse effects (that is, effects remaining after the implementation of all mitigation measures) are significant, based on the defined criteria (BC EAO 2013d). The potential for significant residual adverse effects is a "key consideration in determining whether or not an Environmental Assessment Certificate is issued for a proposed project" (BC EAO 2013d).

Another major objective of an EA application is to measure the impacts of the project and all other past, present and reasonably foreseeable projects and activities in the region (that is, a cumulative effects assessment). The cumulative effects assessment is required if a reviewable project is expected to result in any residual adverse effects on the selected VCs (not only those predicted to be significant). The significance of any cumulative effects must also be evaluated (BC EAO 2013d, 2015a; CEAA 2015a). 
Planning and execution of post-construction monitoring and follow-up studies is the last and one of the most important steps for the EA application. They are intended to monitor adverse project effects and mitigation measures throughout the construction and operations phase and beyond (often including decommissioning and abandonment). It is important to confirm that project impacts are not higher than predicted and that mitigation measures are working as proposed.

reviewed by the provincial or federal responsible authorities to determine their significance. For the majority of the projects with the EA process completed, the regulators' assessment reports concluded that practical means have been identified to prevent or reduce any potential negative environmental impacts of the proposed projects such that no direct or indirect significant adverse effect is predicted or expected. Significant residual adverse effects to the GHG emissions VC and the wildlife VC (specifically, to caribou, grizzly bear and harbour porpoise) reported for a number of projects will be discussed in detail further on.

\section{Potential Cumulative Effects from Natural Gas and LNG Development}

Cumulative effects are changes to environmental, social and economic values caused by the combined effect of past, present and potential future activities and natural processes (BC MFLNRO and BC MEM 2016). They can be classified into a number of types, including habitat alteration, loss and fragmentation; barriers to movement; direct and indirect mortality and disturbance (Salmo Consulting Inc. and Diversified Environmental Services 2003). Exceedance of thresholds (due to overlapping in time and space) and induced effects should also be taken into consideration.

Key challenges in the completion of an adequate cumulative effects assessment were discussed in a number of studies (Salmo Consulting Inc. and Diversified Environmental Services 2003; WWF-Canada and UNBCCIRC 2015) and include:

- Extending the analysis of project level impacts to a regional level.

- Inadequate baseline that does not adequately consider predevelopment conditions.

- Lack of standardized methodological approach, consistency and transparency in defining significance.

- Lack of incorporation of traditional ecological knowledge and Indigenous peoples considerations.

- Lack of acceptance and implementation of thresholds.

- Dealing with uncertainty (for example, imperfect knowledge of 


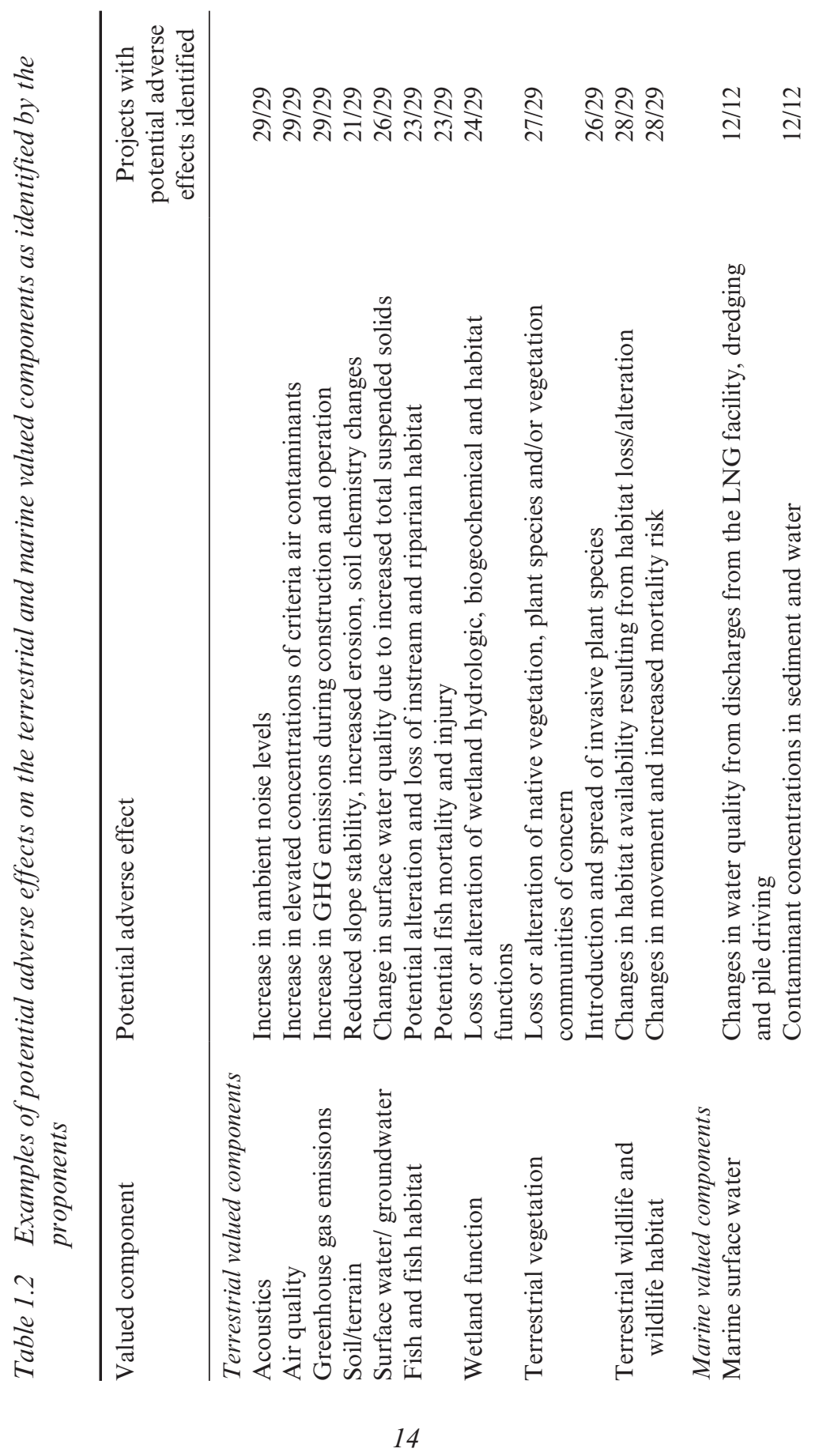




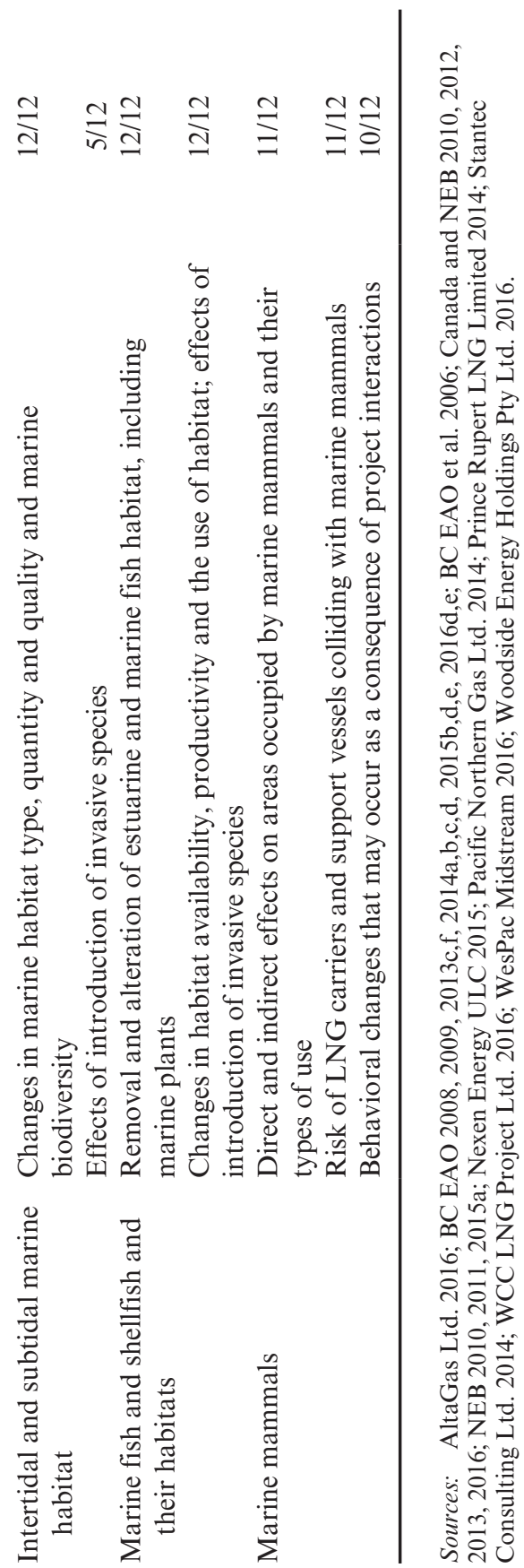


baseline conditions and activities, limited understanding of the indirect impacts of activities and uncertainties about future development scenarios).

- Different interpretation of cumulative effects data.

It is important to remember that small, non-reviewable projects are not currently assessed for cumulative effects, so unintended impacts can accumulate. However, the demand for natural gas infrastructure is growing rapidly, with the context for new development becoming more complex, that results in a need to efficiently and consistently assess the impact of both small and large projects (Province of BC 2014a).

The analysis of cumulative effects from the 18 natural gas pipeline and LNG projects where the provincial or federal EA process has been completed shows that the majority of the proposed projects will not likely result in significant cumulative adverse effects to identified VCs taking into account practical means of preventing or reducing to an acceptable level, any potential adverse effects. However, for the wildlife VC, the cumulative effects were rated as significant for three threatened and endangered species (specifically, caribou, grizzly bear and harbour porpoise) on a number of the assessed projects (BC EAO 2013c, 2014a,b,d, 2016e; CEAA 2016b). These findings can be mostly attributed to the results of long-term habitat fragmentation and ongoing loss and alteration of the natural landscape in the region.

\section{Significant Residual and Cumulative Adverse Effects on the Environmental Valued Components}

\section{Increase in greenhouse gas emissions}

Significant residual adverse effects related to $\mathrm{GHG}$ emissions have been one of the major environmental issues identified by the regulators on seven out of the 18 natural gas pipeline and $\mathrm{LNG}$ projects where the provincial and/or federal EA process has been completed (BC EAO 2009, 2013c, 2014a,b,d, 2015b; CEAA 2016b). GHGs would be released during the construction, operation and decommissioning of the proposed projects. It should be noted that $\mathrm{BC} \mathrm{EAO}$ did not require the proponents to include a cumulative effects assessment for GHG emissions, since they are a global issue.

Both the federal and provincial governments have created strategiclevel plans to address GHG emissions. A target set by the Government of Canada under the Copenhagen Accord (2009) was reducing Canada's total GHG emissions by 17 percent from 2005 levels by 2020. In 2015 the Government of Canada announced its commitment to reducing Canada's GHG emissions by 30 percent below 2005 levels by 2030, which would require cutting current emissions by about 200 million tonnes 
(Mt) (Government of Canada 2015). The BC Greenhouse Gas Reduction Act (2007) establishes provincial GHG reduction targets of 33 percent below 2007 emission levels by 2020 and 80 percent below by 2050 . Interim reduction targets of 6 percent by 2012 and 18 percent by 2016 have been set in policy to guide and measure progress (Province of BC 2008). In 2014 the Province's carbon dioxide equivalent $(\mathrm{CO} 2 \mathrm{e})$ emission levels were reported at 62700 kilotonnes (kt), which is 5.5 percent below 2007 levels (Province of BC 2016b).

In order to achieve the GHG reduction goals across the Province, British Columbia has designed and implemented a number of policy, regulatory and legislative measures. The BC Greenhouse Gas Industrial Reporting and Control Act (2014) establishes a GHG emissions intensity benchmark for $\mathrm{LNG}$ facilities of 0.16 tonnes of $\mathrm{CO} 2 \mathrm{e}$ per tonne of $\mathrm{LNG}$ produced (t CO2e/t LNG). The BC Climate Leadership Plan released in 2016 contains new actions to reduce $\mathrm{GHG}$ emissions across the six main action areas, including natural gas, where annual emissions are expected to be reduced by up to $5000 \mathrm{kt}$ by 2050 (Province of BC 2016b).

Table 1.3 shows estimated GHG emissions (Mt of CO2e per year) at the full operational capacity (full build-out) of the seven natural gas pipeline

Table 1.3 Estimated greenhouse gas emissions at full operational capacity for the proposed natural gas and LNG projects with the significant residual adverse effects identified by the regulators

\begin{tabular}{lcccc}
\hline Project title & $\begin{array}{c}\text { Estimated } \\
\text { GHG } \\
\text { emissions, } \\
\text { Mt CO2e/year }\end{array}$ & \multicolumn{2}{c}{$\begin{array}{c}\text { Contribution to increase } \\
\text { in GHG Emissions, \% }\end{array}$} \\
\hline Cabin Gas Plant & 2.166 & $3.27^{\mathrm{a}}$ & $0.29^{\mathrm{b}}$ & $\mathrm{NA}$ \\
Coastal GasLink Pipeline & 3.517 & $6.0^{\mathrm{c}}$ & $0.50^{\mathrm{c}}$ & 0.012 \\
Fortune Creek Gas & 2.435 & $3.9^{\mathrm{d}}$ & $0.35^{\mathrm{d}}$ & $\mathrm{NA}$ \\
LNG Canada Export Terminal & 3.958 & $6.6^{\mathrm{c}}$ & $0.57^{\mathrm{c}}$ & $\mathrm{NA}$ \\
Pacific NorthWest LNG & 4.5 & $7.2^{\mathrm{e}}$ & $0.62^{\mathrm{e}}$ & 0.015 \\
Prince Rupert Gas & 1.918 & $3.2^{\mathrm{f}}$ & $0.30^{\mathrm{f}}$ & $0.004^{\mathrm{d}}$ \\
$\quad$ Transmission & & & & \\
Westcoast Connector Gas & 4.4 & $7.0^{\mathrm{c}}$ & $0.60^{\mathrm{c}}$ & $0.010^{\mathrm{d}}$ \\
$\quad$ Transmission & & & & \\
\hline
\end{tabular}

Notes: Contribution of the reviewed projects to increase in GHG emissions (\%), as estimated by the regulator or the proponent, is based on the following data: a - 2006 inventory; $\mathrm{b}-2007$ inventory; $\mathrm{c}-2011$ inventory; $\mathrm{d}-2010$ inventory; $\mathrm{e}-2014$ inventory; f - 2012 inventory (Government of Canada 2013).

Sources: $\quad$ BC EAO 2009, 2013c, 2014a,b,d, 2015b; CEAA 2016b. 
or LNG projects with the significant residual adverse effects identified. The table also provides information on the estimated contribution (percent) of each project to increase provincial, national and global GHG emissions. As stated by the proponents, the anticipated GHG emissions are conservative estimates that represent a worst case scenario, meaning that the estimates presented in Table 1.3 are most likely higher than actual emissions at the projects' full build-out.

As shown in Table 1.3, the Pacific NorthWest LNG project would result in approximately $4.5 \mathrm{Mt} \mathrm{CO} 2 \mathrm{e}$ per year (approximately $0.22 \mathrm{t} \mathrm{CO} 2 \mathrm{e} / \mathrm{t}$ LNG), which would represent a marked increase in GHG emissions both at the provincial and national level. In addition to the assessment of the direct GHG emissions, Environment and Climate Change Canada (ECCC) has also assessed the upstream GHG emissions associated with the proposed project, as required in accordance with the Government of Canada's interim approach for EAs announced in 2016 (Government of Canada 2016a). Upstream emissions were estimated for the stages preceding the liquefaction process and included natural gas production, processing and pipeline transmission. According to the ECCC, the upstream GHG emissions associated with the Pacific NorthWest LNG project would represent 14.0-14.7 percent of provincial emissions and 1.2-1.3 percent of national emissions (based on 2014 levels) and would be high in magnitude, continuous, irreversible and global in extent (CEAA 2016b).

As assessed by the ECCC, the proposed project would be amongst the largest single point sources of GHG emissions in the country and would rank third among emitters in the oil and gas sector in Canada. As a result of the federal EA, the Government of Canada approved the Pacific NorthWest LNG project with the imposing of, for the first time ever, a maximum cap on annual project direct GHG emissions (4.3 Mt of CO2e per year, 900000 tonnes less than what had initially been proposed by the proponent) (Government of Canada 2016b).

\section{Impacts on caribou and caribou habitat}

Impacts on caribou and caribou habitat were determined by BC EAO as a significant residual adverse effect on three major natural gas pipeline projects (out of 18 with the EA process completed) and were also determined by the NEB as a key issue that should be considered and fully compensated for on two other natural gas pipeline projects in northeast British Columbia (BC EAO 2014a,b,d; Canada and NEB 2015; NEB 2012). According to BC EAO's assessment reports, four natural gas pipeline projects will contribute to significant cumulative effects on caribou (BC EAO 2013c, 2014a,b,d). For two other natural gas pipeline projects, the NEB concluded that the cumulative adverse effects of the proposed 
projects on caribou and caribou habitat are not likely to be significant, with the implementation of mitigation to offset unavoidable and residual impacts to caribou habitat (Canada and NEB 2015; NEB 2011).

Certain populations of woodland caribou (Rangifer tarandus caribou) in Canada are listed as Threatened under the federal Species at Risk Act (SARA). In British Columbia, certain populations of northern caribou and all populations of mountain and boreal caribou that represent three ecotypes of woodland caribou are provincially listed as Threatened. Conserving caribou in British Columbia is a priority for the government, with the BC Ministry of Environment (BC MOE) supporting the management of all three ecotypes (BC MOE 2016a).

Woodland caribou in British Columbia are believed to be in decline that may be attributed to habitat loss, fragmentation of the herd, alteration of their habitat and increased predation, resulting from forestry and petroleum and natural gas activities (BC MEM 2012). Any additional residual loss of habitat, increase in mortality or increase in displacement/disturbance from critical habitat or important connections to critical habitat in the area of the proposed projects will have a serious impact on the potential for recovery of caribou subpopulations. Caribou are likely to alter their movement to avoid noise, activity and disturbance associated with construction activities, as well as noise from permanent facilities. The pipeline right-of-way and additional linear development could provide a travel route for predators. Available mitigation to reduce impacts of increased predation are still unproven and cannot be relied upon to completely reduce those effects (BC EAO 2014a,b,d; Canada and NEB 2015; NEB 2015c).

For the three projects (Westcoast Connector Gas Transmission, Prince Rupert Gas Transmission and Coastal GasLink Pipeline) where the significant adverse effect on caribou was identified, the primary factors leading to the BC EAO's rating of significance were the long-term potential impacts from the proposed projects of enhanced predator access to caribou (BC EAO 2014a,b,d).

For the four reviewed projects (Westcoast Connector Gas Transmission, Prince Rupert Gas Transmission, Coastal GasLink Pipeline and Fortune Creek Gas Project), BC EAO concluded that the residual effects of habitat disturbance, sensory disturbance and creation of access from the proposed projects would likely interact with reasonably foreseeable future projects to create cumulative effects. Taking into account the significant project effects and the sensitivity of caribou to further disturbances, the cumulative effects to caribou were considered to be significant (BC EAO 2013c, 2014a,b,d).

In the NEB's reports for the North Montney Mainline, Northwest Mainline Expansion and the Horn River Gas projects, the Board concluded 
that all residual effects on caribou habitat should be considered and fully compensated for, given the conservation status of caribou, the presence of critical habitat in the projects' area and the already substantial ongoing cumulative effects on the landscape and caribou in the region (Canada and NEB 2015; NEB 2011, 2015c).

\section{Cumulative impacts on grizzly bear}

Cumulative adverse effects on the grizzly bear population were considered to be significant on one natural gas project out of the 18 where an EAC, EADS or CPCN were issued (BC EAO 2016e).

Grizzly bear (Ursus arctos) is a Blue-listed species (Special Concern) by the $\mathrm{BC}$ Conservation Data Centre and is designated as a Special Concern by the Committee on the Status of Endangered Wildlife in Canada (COSEWIC). Grizzly bears are sensitive to human disturbance, with the cumulative effects of human disturbance being the largest threat to bear populations. As identified by the BC MOE, this impacts bears in three main ways (which can often be overlapping): 1) increase in frequency of conflicts between bears and humans; 2) isolation of bear populations because of human settlements, utility corridors or agriculture, and 3) degradation, loss, fragmentation or alienation of habitat due to developments. In particular, roads are known to have a negative effect on grizzly bear. At the regional scale, open road density higher than $0.6 \mathrm{~km} / \mathrm{km}^{2}$ is known to adversely affect habitat use and these effects are magnified when road density increases over approximately $1 \mathrm{~km} / \mathrm{km}^{2}$ (Environmental Reporting BC and BC MOE 2012).

The existing average motorized access density within the area that would be intersected by the proposed Eagle Mountain - Woodfibre Gas Pipeline project currently exceeds the minimum threshold for high risk of mortality and displacement for two grizzly bear population units (GBPUs) transected by the proposed project. Both units are provincially considered threatened, with core grizzly bear habitat currently remaining well below the recommended minimum target levels (although the habitat loss that would be attributed to the proposed project is negligible). Disturbance from noise created by roads and linear corridors was found to adversely affect grizzly bear habitat effectiveness, to fragment habitat by creating barriers or filters to movement and alienating bears from suitable habitat and to increase mortality risk. It has also been identified that any impacts to the reproductive potential of breeding females could significantly affect the ability for recovery of grizzly bears in these two units traversed by the proposed project. Based on the information summarized here, BC EAO has concluded that while the proposed project alone does not have significant adverse effects to grizzly bears, cumulative effects to this spe- 
cies are considered to be significant, taking into account the effects from past and existing projects and activities on grizzly bears, the threatened status of these GBPUs and reasonably foreseeable projects and activities (BC EAO 2016e).

\section{Impacts on harbour porpoise}

An analysis of EA reports for six provincially and/or federally approved natural gas pipeline and LNG projects that include the marine resources VCs was conducted. While it revealed impacts to marine mammals to be a concern for several projects, only one project has considered residual adverse environmental effects (including cumulative adverse effects) on marine mammals (particularly on harbour porpoise) to be significant (CEAA 2016b).

Harbour porpoise (Phocoena phocoena) listed as a Special Concern by the COSEWIC and SARA, is highly sensitive to acoustic disturbance (particularly underwater noise), shows strong site fidelity and a higher degree of behavioral response to similar disturbances compared to other marine mammals (CEAA 2016b; DFO 2009). The CEA Agency concluded that the proposed Pacific NorthWest LNG project is likely to cause significant adverse environmental effects to harbour porpoise, given its susceptibility to behavioral effects from underwater noise, its current at-risk status, its extensive use of the project area year-round and the uncertainty of suitable alternative habitat. The regulator also concluded that the proposed project is likely to result in significant adverse cumulative environmental effects to harbour porpoise, given the number of large industrial projects proposed in the Prince Rupert area that could increase underwater noise and considering that behavioral effects of overlapping projects are expected to occur over a larger area and for a longer period of time. (CEAA 2016b; MOE 2016).

\section{MAJOR INDIGENOUS PEOPLES' ISSUES INFLUENCING NATURAL GAS AND LNG DEVELOPMENT IN BC}

\section{Indigenous Peoples in BC}

The Indigenous, ${ }^{2}$ or Aboriginal peoples, are the descendants of the original inhabitants of North America. Section 35 of the Constitution Act (1982) recognizes three distinct groups of Aboriginal peoples: First Nations people (previously known as Indians ${ }^{3}$ ), Métis and Inuit. BC's Indigenous population, based on Statistics Canada 2011 census data, 
consists of 232280 people, which represented 5.3 percent of the total BC population (Statistics Canada 2013).

There are 198 First Nations in British Columbia that represent about one-third of all First Nations in Canada. First Nations population in BC, as per Statistics Canada 2011 census data, consists of 155015 people, or 67 percent of the total Indigenous population in BC (Statistics Canada 2013). With a total population in BC of 4400057 in 2011, First Nations represented 3.5 percent of the total population. Indigenous peoples in $\mathrm{BC}$ represented 17 percent of Canada's Indigenous population, while First Nations people in BC represented 19 percent of Canada's First Nations people. While BC has fewer than one-fifth of Canada's Indigenous and First Nations people, it is characterized by the greatest diversity of Indigenous cultures in Canada, including seven of Canada's 11 unique language families that are located exclusively in $\mathrm{BC}$ and represent more than 60 percent of the First Nations languages in Canada (INAC 2010a).

The Métis are originally the people of mixed First Nations-European ancestry, the descendants of eighteenth-century unions between European men (explorers, fur traders and pioneers) and First Nations women. Within a few generations the descendants of these unions developed a culture distinct from their European and First Nations forebears (RCAP 1996). Métis population in BC, as per Statistics Canada 2011 census data, consists of 69470 people, or 30 percent of the total Indigenous population in BC (Statistics Canada 2013).

Inuit are the Aboriginal people of Arctic Canada that live primarily in Nunavut, the Northwest Territories, Labrador and Northern Quebec. Inuit population in $\mathrm{BC}$, as per Statistics Canada 2011 census data, consists of 1570 people, or 1 percent of the total Indigenous population in $\mathrm{BC}$ (Statistics Canada 2013).

\section{Aboriginal and Treaty Rights and Canadian Aboriginal Law}

Indigenous peoples struggled for recognition of their rights and fair treatment in their relations with European settlers long before establishing the Canadian Confederation in 1867. Canadian Aboriginal law has developed as a response to the actions of government and/or as a tool used by Indigenous peoples in their struggle. Box 1.3 provides a succinct summary of main documents defining the legal relationship between the Crown and Indigenous peoples and major legal cases with landmark judgments clarifying the nature of Aboriginal rights and titles.

It is important to understand that Aboriginal rights differ from treaty rights. Aboriginal rights are not clearly defined and must be established 


\section{BOX 1.3 CANADIAN ABORIGINAL LAW AND MAJOR LEGAL CASES CLARIFYING THE NATURE OF ABORIGINAL RIGHTS AND TITLE}

- Royal Proclamation (1763) was the first important step toward the recognition of existing Aboriginal rights and title, including the right to self-determination. It is also set a foundation for the process of establishing treaties (UBC First Nations and Indigenous Studies 2009).

- Section 35 of the Constitution Act (1982) recognizes and affirms existing Aboriginal and treaty rights; however, the nature, scope or extent of these rights were not defined in the Act.

- Calder v. Attorney-General of British Columbia (1973). The Supreme Court of Canada's (SCC) decision was the first of a series of landmark judgments to deal with Aboriginal rights. For the first time, the existence of Aboriginal title to land was acknowledged that would later lead to the BC Treaty Process and the settling of the first modern-day land claim in BC's history, the Nisga'a Final Agreement in 1998 (BC Treaty Commission 2008; SCC 1973).

- R. v. Sparrow (1990). The SCC made a precedent-setting decision that establishes a list of criteria to determine whether an Aboriginal right is existing, and if so, how a government may be justified to infringe upon it (BC Treaty Commission 2008; SCC 1990).

- Delgamuukw v. British Columbia (1997). The SCC's decision in the Delgamuukw case confirmed that Aboriginal title does exist in $\mathrm{BC}$ and that it's a right to the land itself, not just the right to hunt, fish or gather. When dealing with the Crown land, the Government must consult with, and may have to compensate, First Nations whose rights may be affected (BC Treaty Commission 1999, 2008; SCC 1997).

- R. v. Powley (2003) was the first major Aboriginal rights case concerning Métis peoples. The SCC's decision resulted in the Powley test, which laid out a set of criteria to not only define what might constitute a Métis right, but also establishes who can legally qualify for Métis rights (INAC 2016b; SCC 2003).

- Haida Nation v. British Columbia (Minister of Forests) (2004). The SCC established that the Crown is required to consult with Aboriginal groups with respect to Crown-authorized activities that might affect Aboriginal interests, and that the extent of the consultation is proportionate to 1) preliminary assessments of strength of the case for the claimed Aboriginal rights and title; and 2) seriousness of the potential impact of Crown action or activity on Aboriginal interests (BC EAO 2015b; BC Treaty Commission 2008; SCC 2004a). The court strongly urges the parties to negotiate rather than litigate, noting that "while Aboriginal claims can be and are pursued through litigation, negotiation is a preferable way of reconciling state and Aboriginal interests" (SCC 2004a).

- Taku River Tlingit First Nation v. British Columbia (Project Assessment Director) (2004). Similar to the Haida case, the SCC ruled that the Province should have consulted with the First Nations about the decisions, and possibly accommodated Aboriginal interests, even though the First Nations had not legally proved the existence of their Aboriginal rights and title (Olynyk 2005; SCC 2004b). 
- Mikisew Cree First Nation v. Canada (Minister of Canadian Heritage) (2005). The SCC extended the Crown's obligation to consult and accommodate Aboriginal interests (established earlier in the Haida and Taku cases) in order to include existing treaty rights (BC Treaty Commission 2008; SCC 2005). These general principles were later reaffirmed in the Grassy Narrows First Nations v. Ontario (Natural Resources) case (SCC 2014b).

- Tsilhqot'in Nation v. British Columbia (2014). The SCC's Tsilhqot'in decision (2014) clarified the test for Aboriginal title relating to the elements of sufficient and exclusive occupation at the time of assertion of European sovereignty in 1846 (SCC 2014a). This is the first time that any court has formally declared that Aboriginal title exists to a particular tract of land outside of a reserve. The SCC's decision also stated that without consent from First Nations which hold Aboriginal title to land, the government cannot approve developments on that land unless this infringement can be justified (SCC 2014a; Tsilhqot'in National Government 2014).

- Coastal First Nations v. British Columbia (Environment) (2016). The BC Supreme Court held that a portion of the Equivalency Agreement between $\mathrm{BC} E A O$ and the NEB was invalid and ruled that the Province cannot rely on Canada to discharge its constitutional duties of consultation and accommodation due to jurisdictional overlap (BCSC 2016; Robe and Dean 2016).

on a case-by-case basis, whereas treaty rights are negotiated and can be exhaustively set out and described in detail.

The history of treaty making in British Columbia has been substantially different than it has been for the rest of Canada. In the past, the majority of BC's Indigenous groups did not sign treaties, except for eight First Nations in the northeast quarter of BC, the signatories to Treaty 8 in 1899 (BC MARR 2016f). Until the negotiation of the Nisga'a Final Agreement (1998), almost all of the Province remained subject to outstanding Aboriginal land claims (INAC 2010b). The courts have confirmed that Aboriginal title still exists in $\mathrm{BC}$, but they have not indicated where it exists. To resolve this situation, in 1993 the British Columbia Treaty Commission was established to facilitate the negotiation of treaties (BC Treaty Commission 2008).

Currently, the Government of Canada, along with the Province, is negotiating with approximately 70 percent of BC's First Nations through the BC Treaty Process (INAC 2010a). There are 65 First Nations that are participating in or have completed treaties through this negotiation process (BC Treaty Commission 2016). There are four First Nations that have already completed the six-stage BC Treaty Process and have their treaty final agreements ratified and implemented (BC MARR 2016b; INAC 2016a). 


\section{The Crown's Duty to Consult with Indigenous Peoples Within the Environmental Assessment Process}

In accordance with Section 35 of the Constitution Act (1982), the Crown is legally obligated to consult on and, if necessary, accommodate asserted or established Aboriginal rights including Aboriginal title or treaty rights that may be impacted by Government decisions. This duty also stems from Canadian common law as expressed in court decisions. In the case of asserted Aboriginal rights and title, the scope of consultation is based on an assessment of the strength of claim and the seriousness of potential impacts upon the asserted rights. In the case of proven Aboriginal rights or treaty rights, the scope of consultation is based on the seriousness of the potential impact on the right (BC EAO 2013e; Province of BC 2010).

$\mathrm{BC} \mathrm{EAO}$ as the provincial responsible authority is obliged to consult and accommodate Aboriginal groups, in keeping with the Supreme Court of Canada's direction in the Haida (SCC 2004a) and Tsilhqot'in (SCC 2014a) decisions (see Box 1.3 for details). The extent of the Crown's obligation to consult is described in the Haida case as lying on a spectrum from notification to deep consultation, primarily regarding on the proximity of the proposed project to an Aboriginal group's asserted traditional territory. BC EAO also considers the Tsilhqot'in decision in the EA process, and the BC EAO's assessment of whether Aboriginal groups may have a prima facie claim to Aboriginal rights or title is intended to inform the level of consultation required for each Aboriginal group for the proposed project that can be potentially affected by the Crown's activities. Consultations with Aboriginal groups at the higher end of the consultation spectrum include notification of key milestones, opportunities to review and comment on key documents, participation in the working group and procedural consultations. Consultations with Aboriginal groups at the lower end of the spectrum include notification of key milestones, invitation to meet with $\mathrm{BC} \mathrm{EAO}$ to discuss any Aboriginal interests in the proposed project area and invitation to review and comment on the EAO's draft assessment report (BC EAO 2013e).

Announced by the Federal Government in 2016 interim principles for projects currently undergoing an EA process (see Box 1.1 for details), stipulating that Indigenous peoples will be meaningfully consulted and where appropriate, impacts on their rights and interests will be accommodated, have been recently applied to two projects: Pacific NorthWest LNG and Towerbirch Expansion (Government of Canada 2016a,b; NEB 2016). The former is an example of the successful application of these interim principles, including extensive consultations with Indigenous communities with funding of over $\$ 480000$ provided to support their participation in the 
EA and establishing environmental monitoring committees comprised of Indigenous peoples and federal and provincial representatives, for the first time ever (Government of Canada 2016b).

\section{Potential Impacts on Indigenous Peoples' Interests Identified in the Environmental Assessment Process}

A summary of the most common potential adverse impacts from the reviewed natural gas pipeline and LNG projects on Indigenous peoples' interests is provided in Table 1.4. Data in the table are based on the review of EA reports prepared by BC EAO, the NEB or CEA Agency for the 18 projects where the provincial or federal EA process has been completed since 2010.

Some other common concerns raised by Indigenous groups throughout the provincial or federal EA process for the natural gas pipeline and LNG projects included:

- Economic development, business and employment opportunities and training.

- Economic effects including labor availability and wage inflation.

- Social effects, including housing availability and affordability.

- Impacts to community infrastructure, healthcare and emergency response.

- Accidents or malfunctions (for example, LNG vessel spills leading to contamination of shellfish; spill response plan; accidents at the facility).

- Environmental management plans, follow-up, monitoring and reporting.

- EA methodology regarding baseline information and VCs selection.

- Inadequate consideration of traditional land use/traditional ecological knowledge studies.

- Consultation (adequacy; determining who to consult; what constitutes consultation).

For several LNG projects where the provincial and/or federal EA processes are currently underway (including projects at pre-application stage with $\mathrm{BC}$ EAO), proponents anticipate that the following concerns may be raised by Aboriginal groups specifically with regard to potential impacts of the projects on the marine VCs (AltaGas Ltd. 2016; Nexen Energy ULC 2015; Prince Rupert LNG Limited 2014; Woodside Energy Holdings Pty Ltd. 2016): 
Table 1.4 Examples of potential adverse impacts on Indigenous peoples' interests identified in the environmental assessment process

\begin{tabular}{|c|c|c|}
\hline $\begin{array}{l}\text { Valued } \\
\text { component/ key } \\
\text { indicator }\end{array}$ & Potential adverse impact & $\begin{array}{l}\text { Projects with } \\
\text { potential adverse } \\
\text { impact identified }\end{array}$ \\
\hline \multirow{3}{*}{$\begin{array}{l}\text { Health and } \\
\text { socio-economic } \\
\text { conditions }\end{array}$} & $\begin{array}{l}\text { Change in human health - harvested } \\
\text { foods, water quality, air emissions, noise }\end{array}$ & $18 / 18$ \\
\hline & $\begin{array}{l}\text { Reduction in visual quality and change } \\
\text { to the acoustic environment in areas of } \\
\text { identified concern to Aboriginal owned } \\
\text { or operated businesses }\end{array}$ & $9 / 18$ \\
\hline & $\begin{array}{l}\text { Change in the availability of harvested } \\
\text { foods for use by Aboriginal owned or } \\
\text { operated businesses }\end{array}$ & $17 / 18$ \\
\hline \multirow[t]{3}{*}{$\begin{array}{l}\text { Physical and } \\
\text { cultural heritage }\end{array}$} & $\begin{array}{l}\text { Alteration or loss of site-specific } \\
\text { traditional land use }\end{array}$ & $18 / 18$ \\
\hline & Change in cultural practices & $17 / 18$ \\
\hline & $\begin{array}{l}\text { Changes to intangible heritage resources/ } \\
\text { expression of cultural values or ways of } \\
\text { knowing }\end{array}$ & $17 / 18$ \\
\hline \multirow{3}{*}{$\begin{array}{l}\text { Current use } \\
\text { of lands and } \\
\text { resources for } \\
\text { traditional } \\
\text { purposes }\end{array}$} & $\begin{array}{l}\text { Alteration of traditional subsistence } \\
\text { activities, such as hunting, fishing, } \\
\text { gathering and trapping }\end{array}$ & $18 / 18$ \\
\hline & $\begin{array}{l}\text { Depletion of resources within Aboriginal } \\
\text { traditional territories due to an increase } \\
\text { in access }\end{array}$ & $18 / 18$ \\
\hline & $\begin{array}{l}\text { Changes in preferred harvested species } \\
\text { and traditional use sites }\end{array}$ & $15 / 18$ \\
\hline $\begin{array}{l}\text { Structure/site } \\
\text { of historical or } \\
\text { archeological } \\
\text { significance }\end{array}$ & $\begin{array}{l}\text { Alteration/removal of archaeological/ } \\
\text { cultural heritage sites, sacred sites, trails } \\
\text { and culturally/spiritually important sites } \\
\text { and culturally modified trees }\end{array}$ & $18 / 18$ \\
\hline
\end{tabular}

Sources: $\quad$ BC EAO 2008, 2009, 2013c, 2014a,b,c,d, 2015b,e, 2016e; BC EAO et al. 2006; Canada and NEB 2015, 2016; CEAA 2013, 2016b; NEB 2015b,d.

- Change in area available and/or accessible for marine fisheries and shoreline harvesting.

- Interference with Aboriginal fishing vessels and activities by vessel traffic and/or LNG shipping.

- Inhibiting Aboriginal groups' access to preferred fishing locations due to LNG shipping. 
- Marine surface water quality (potential issues from vessel propeller turbidity, disposal at sea, dredging, including toxicity of disturbed sediments).

- Marine fish and shellfish and their habitat (impacts of vessel wake on fish and fish habitat; potential affect to fish habitat due to ambient lighting issues and/or as a result of shadowing at the berth facility).

- Marine mammals (changes to behavior of marine mammals from LNG carriers and tugs, due to pressure waves and underwater noise; and direct mortality to marine mammals from ship strikes).

- Cumulative effects to marine use and resources.

Cumulative effects remain a matter of critical importance for various Aboriginal groups potentially impacted by proposed natural gas pipeline and LNG projects. Many of them expressed concerns about the inadequacy of the cumulative effects assessment of past, present and reasonably foreseeable industrial activity in their traditional territory. Specifically, cumulative effects in northeast $\mathrm{BC}$ at a regional scale have been a concern of the Treaty 8 First Nations, including Blueberry, Saulteau, West Moberly and Fort Nelson First Nations, who are of the view that industrial development in the Western Canadian Sedimentary Basin and northeast $\mathrm{BC}$ has already and will continue to result in a reduced ability to exercise their treaty rights (Canada and NEB 2016).

\section{Significance of Potential Impacts to Aboriginal Interests}

The general BC EAO conclusion for the vast majority of the reviewed projects is that although there could be potential impacts to resources or values of importance to Aboriginal groups, the majority of this disturbance and impact would be expected to be short- to medium-term, during and following construction, and would be reversible shortly after construction. Assessment reports provided by BC EAO for each project with the completed provincial EA process concluded that the potential for adverse effects on the Aboriginal rights and Treaty 8 rights of Aboriginal groups has been avoided, minimized or otherwise accommodated to an acceptable level, and the provincial Crown has fulfilled its obligations for consultation and accommodation to Aboriginal groups relating to the issuance of an EAC for the proposed projects.

For 17 of the 18 projects discussed in this section, with the provincial or federal EA processes completed, both BC EAO or NEB have been of the view that no significant adverse effects on the Aboriginal interests will occur as a result of the proposed projects, with the implementation 
of impacts and benefits and other agreements (including follow-up environmental management and monitoring program agreements) established by the proponents with Aboriginal groups to address Aboriginal interests in relation to the proposed projects. The majority of issues raised during the review processes by Aboriginal groups were satisfactorily addressed through existing, revised or new commitments and project design changes made by the proponents, who have made efforts to avoid high value areas for Aboriginal groups (for example, by building on existing industrial lands, minimizing clearing wherever possible and providing appropriate mitigation measures to reduce the potential effects of project shipping).

\section{Aboriginal Consultation and Engagement Issues}

In 2015 Squamish Nation entered into separate agreements with the proponents of the Eagle Mountain - Woodfibre Gas Pipeline Project and the Woodfibre LNG Project that set out a process between the parties to discuss Squamish Nation's EA of the two projects. This included an assessment of the potential effects of those projects on Squamish Nation's asserted Aboriginal rights and title (the "Squamish Process"). As identified by Squamish Nation, there was a number of environmental issues of concern that may potentially affect their Aboriginal interests (BC EAO 2015e, 2016e). As a result of the Squamish Process, Squamish Nation approved the Woodfibre LNG EA Agreement and issued an EAC to the proponent (subject to the 13 conditions) and an EA Agreement in support of the Eagle Mountain Project (subject to the nine conditions). The negotiating team made it clear that the proponents and the Province must meet all of the Squamish Nation's legally binding conditions, otherwise, Squamish Nation can either revoke the EA Agreements or pursue legal remedies in court to force the proponents to comply with the conditions (Squamish Nation Chiefs and Council 2016; Woodfibre LNG 2016).

The Nak'azdli Whut'en First Nation announced in 2016 it would not proceed with any of agreements at this time involving the Coastal GasLink and Prince Rupert Gas Transmission Projects (Pynn 2016). The Luutkudziiwus, a Gitxsan Nation House Group, was strongly opposed to the Prince Rupert Gas Transmission Project, which crosses $34 \mathrm{~km}$ of their traditional territory. As of 2016 this Gitxsan Group was raising funds to launch a court challenge to overturn provincial approval and permits for the project on the basis they were not consulted (Hoekstra 2016). In January 2017 Gitxsan Nation Hereditary Chiefs announced a fourth federal lawsuit against the federal approval of the Pacific Northwest LNG project claiming the project would infringe their Aboriginal fishing rights (Jang 2017). 
The Tsawwassen First Nation's rejection to an LNG export facility on their territory near Delta, BC, represents an example of the difference of opinions within an Aboriginal community. While the leadership of the Tsawwassen First Nation had initially been supportive of the project, in 201553 percent of the band members voted to reject plans to build the proposed LNG facility on their traditional lands. As a result of the vote, the Tsawwassen First Nation said it would not be moving forward with any additional discussion regarding this proposed LNG concept (Canadian Press 2015).

\section{KEY APPROACHES TO ADDRESS ENVIRONMENTAL AND INDIGENOUS PEOPLES' ISSUES IDENTIFIED ON NATURAL GAS AND LNG PROJECTS}

\section{Mitigation Measures to Avoid or Reduce Potential Adverse Effects}

When the provincial or federal EA process for a major natural gas pipeline or an LNG project is completed and approval is granted, an EAC, a CPCN or an EADS is issued, subject to the terms and conditions, including project design restrictions. The specified conditions form a part of the certificate or the decision statement and represent legally binding requirements that the proponent must meet to be in compliance with the certificate for the proposed project. It is not uncommon for an EA certificate to have over 100 commitments. For the 12 reviewed projects that have been approved by the provincial regulator (BC EAO), the amount of legally binding conditions for each project ranges from eight (Pacific NorthWest LNG) to 243 (Kitimat LNG Terminal). For the 11 reviewed projects that have been approved by the federal regulators (the NEB or the CEAA Agency) the amount of commitments for each project varies from 28 (Northwest Mainline Expansion) to over 190 (Pacific NorthWest LNG). Mitigation conditions proposed by the provincial and federal regulatory authorities do not necessarily overlap, and the federal agency may propose additional mitigation for consideration by the federal Minister of Environment as legally binding conditions in an EADS under the CEA 2012 (as it can be seen in the Pacific NorthWest LNG's case).

Certificate conditions are generally based on the results of consultation and input from Indigenous peoples, government agencies, communities and the public. To avoid or decrease potential adverse effects, proponents can also propose a number of pipeline route changes implemented as 
project design restrictions based on feedback and input from Indigenous groups and the technical working groups during the EA process.

Box 1.4 summarizes various types of mitigation to avoid or reduce potential adverse environmental effects of designated projects. Table 1.5 provides examples of some common mitigation measures split by the type of mitigation (a priority level in the mitigation hierarchy) based on the analysis of the legally binding conditions in the EACs, CPCNs or EADSs for the 18 reviewed natural gas pipeline and LNG projects where the provincial and/or the federal EA process has been completed.

\section{Environmental Management Plans and Follow-up Programs}

Environmental management plans (EMPs) would be required for all phases of proposed projects to implement mitigation measures and best management practices. EMPs and follow-up programs are usually developed in consultation with appropriate regulatory agencies, Indigenous groups and key stakeholders.

Some of the EMPs and follow-up programs would be required by the provincial and/or federal agencies or authorities, while others would be incorporated into the EAC conditions as commitments made by the proponent. Examples of the most common EMPs identified through the analysis of the EA applications in relation to the environmental effects from the reviewed projects include plans for: an emergency response; erosion and sediment control; fish habitat offsetting; GHG management; invasive plant management; marine activities; noise management; waste management; wetland compensation; and so on (BC EAO 2015b,e; CEAA 2016b). Examples of the follow-up programs identified from the analysis of the EA applications for the reviewed projects include monitoring programs for: air quality; marine and surface water quality; fisheries and aquatic life; wildlife; vegetation, and so on (BC EAO 2015b,e; CEAA 2016b).

\section{Examples of Key Strategies and Progressive Programs Proposed by the Province}

Numerous regulatory and legislative measures to reduce GHG emissions across the Province have been implemented since 2008, including the provincial carbon tax; carbon-neutrality mandate for all public sector operations; mandatory GHG emissions reporting program for industrial facilities; potential cap-and-trade program and compliance offset scheme for large final emitters (BC MOE 2016b). In 2014 the Provincial 


\section{BOX 1.4 MITIGATION MEASURES TO AVOID OR REDUCE POTENTIAL ADVERSE EFFECTS}

The CEAA 2012 defines mitigation measures as "measures for the elimination, reduction or control of the adverse environmental effects of a designated project, and includes restitution for any damage to the environment caused by those effects through replacement, restoration, compensation or any other means." The BC MOE defines a mitigation measure as action taken "to avoid, minimize, restore on-site, or offset impacts on environmental values and associated components, resulting from a project or activity" (BC MOE 2014b). According to BC EAO, compensation may include not only direct physical measures (for example, habitat enhancement, restoration or creation), but also financial mechanisms (for example, contributions to research and recovery plans, population enhancement programs, and so on) for reducing the residual effect of a project (BC EAO 2013d).

Various types of mitigation can be prioritized in a hierarchy starting with the highest priority (avoidance). All feasible measures at the level of higher priority should be considered before moving to the next one of lower priority, with a rationale provided for this approach. However, it is not necessarily the case in practice, since moving through the hierarchy may not be completely linear (BC EAO 2013d; BC MOE 2014b).

Avoidance should be considered at the initial project planning and route selection process. It can include assessing multiple pipeline route options within the proposed corridor and limiting the potential for adverse effects through route selection (for example, avoiding sensitive wildlife or wetlands habitat; avoiding key areas known to be important for Indigenous peoples; cooperating with another proponent in the same area and utilizing existing access roads where possible to reduce the project footprint). Impacts on some VCs within a project study area can be avoided through application of alternative timing for the project activities (for example, scheduling the clearing and construction activities to avoid the nesting period for migratory birds and restricted periods set out to protect watercourses and SARA-listed species) (BC EAO 2013d; BC MOE 2014b).

Minimization as the next highest priority for application of mitigation should be considered when avoidance measures have been depleted or they are not feasible. The same procedures as those considered for avoidance can generally apply to minimization as well, since minimize means to partially avoid the level of impacts on VCs. It can also be considered at the initial route selection process (for example, locating the pipeline route along previously disturbed areas, including existing forestry cutblocks and access roads to reduce the overall proposed project footprint and minimize habitat fragmentation) (BC MOE 2014b).

Restoration on-site involves returning the impacted ecosystem to a sustainable ecological pathway. Unlike the minimization measures, restoration may be implemented or completed at a future date. In the order of preference, the restore on-site measures include restoration, remediation and reclamation. To restore environmental VCs is usually much more expensive than it would be to conserve them by avoidance or by minimization of impacts (BC MOE 2014b). Monitoring and evaluation of the restoration for effectiveness is critical for determining whether the restoration project is achieving its targets. 
Offset is the lowest priority in the mitigation hierarchy, and it should be implemented only after all previous steps to fully avoid, minimize and restore on-site have been properly considered. The responsibility for offsetting (either direct or indirect) rests with the proponent, who must provide the costs associated with offsetting by an in-lieu payment (BC MOE 2014b).

Government issued the Greenhouse Gas Industrial Reporting and Control Act that requires proponents to achieve an emissions intensity benchmark of $0.16 \mathrm{CO} 2 \mathrm{e} / \mathrm{t} \mathrm{LNG}$.

The BC MOE with support from Provincial Government agencies has developed management plans and recovery strategies to reduce the expected decline in caribou populations in BC, including the Implementation Plan for the Ongoing Management of Boreal Caribou in British Columbia (2011); the Interim Operating Practices for Oil and Gas Activities in Identified Boreal Caribou Habitat in British Columbia (2011); the Mountain Caribou Recovery Implementation Plan (2007) and other documents (BC MEM 2012; BC MOE n.d., 2011, 2014a; Government of BC 2011).

The Province is also moving forward with initiatives that aim to assess and manage cumulative effects to key values, including vegetation and wildlife values, and to consider the impact to Aboriginal rights (BC EAO 2016d). Examples of those initiatives include, but are not limited to, the Cumulative Effects Framework, Area-Based Analysis, Northeast Water Strategy and Water Tool, LNG Environmental Stewardship Initiative and Regional Strategic Environmental Assessment (BC MARR 2016d; BC MFLNRO and BC MEM 2016; BC OGC 2015b,d; Province of BC 2015, 2016c).

\section{Indigenous Peoples: Consultations, Engagement and Agreements}

While the duty to consult Indigenous peoples rests with the Crown, the procedural aspects of consultation may be delegated to proponents. They are encouraged to engage with Indigenous peoples as early as possible in the planning stages in order to build relationships and continue throughout the lifecycle of the project (BC EAO 2013e; BC MARR 2016a). The Province of BC, BC EAO and BC Ministry of Aboriginal Relations and Reconciliation (BC MARR) have developed a number of guidelines to assist proponents with meeting obligations to consult with Indigenous peoples (BC EAO 2013e; BC MARR 2014a, 2016a; Province of BC n.d., 2010). The proposed guidelines adopt a four-phased approach to the consultation procedures, including the preparation, engagement, 


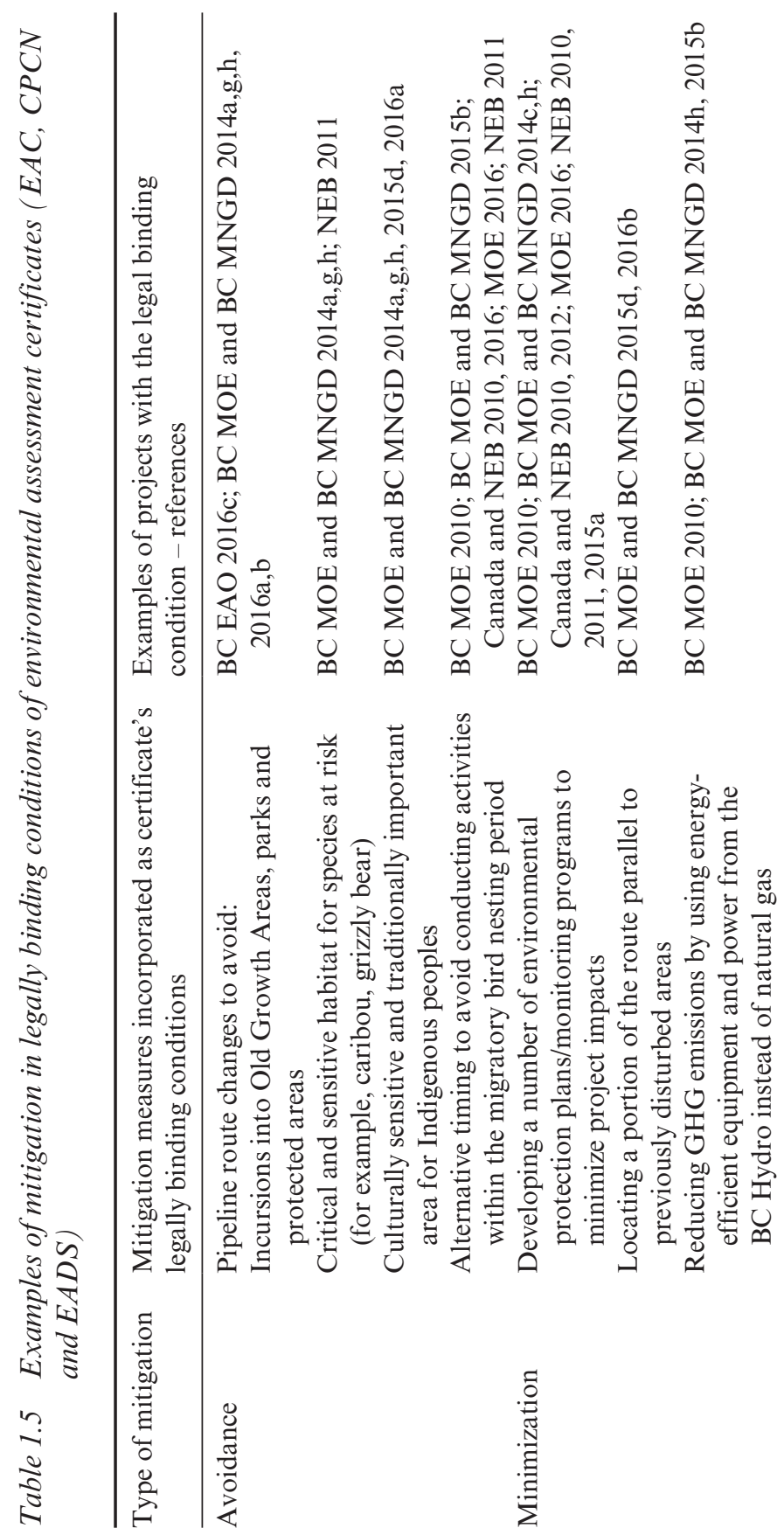



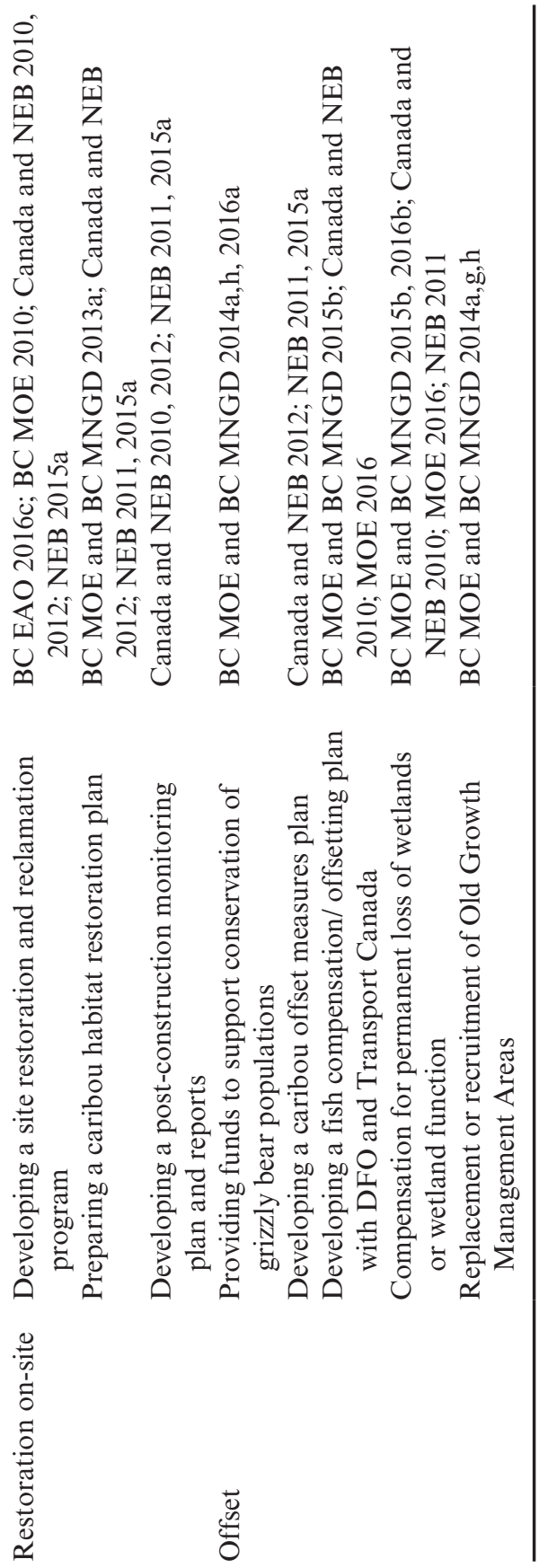
accommodation, decision and follow-up phases each consisting of three to five steps (BC MARR 2014a; Province of BC n.d., 2010).

Agreements with Indigenous peoples can help with building effective relationships and progressing toward sustainable and resilient Aboriginal communities. There are various types of agreements with Indigenous groups that have been negotiated within the Province to date; those specific to the natural gas and LNG industry include, but are not limited to, the LNG Environmental Stewardship Initiative, capacity-building initiatives and economic benefit agreements (BC MARR 2015c, 2016c,d,e).

\section{LNG Environmental Stewardship Initiative}

A new form of collaboration between the Province, Indigenous peoples (involving 32 First Nations as of July 2015) and the LNG sector that was established to ensure the balance between the environment and economic growth, provide strong environmental legacies related to LNG development and produce high quality, trusted and accessible environmental information (BC MARR 2014b, 2015b, 2016d). The Regional Strategic Environmental Assessment developed under the Stewardship Initiative aims to assess the cumulative effects of natural resource development activities on environmental VCs related to the Treaty 8 rights of the participating First Nations in northeast British Columbia (Province of BC 2016c).

\section{Capacity-building initiatives}

The Province is working with Indigenous peoples on all aspects of LNG opportunities in $\mathrm{BC}$ that include skills training, employment, consultation and accommodation work in regulatory decision-making and economic benefits sharing. In 2015 the Province launched a new Aboriginal Skills Training Development Fund that is an investment of up to $\$ 30$ million over the next three years for new Aboriginal skills training projects and partnerships. The overall goal of this program is adding 15000 more Indigenous workers to the Province's workforce within ten years (BC MARR 2015a,c). As of June 2016, more than 1000 Indigenous peoples have already benefited from the training programs, with 85 percent graduating and finding a job (Pynn 2016).

Proponents of natural gas pipeline and LNG projects also have the potential to provide important economic opportunities for Indigenous peoples, including capacity-building initiatives to support employment, contracting and business development. Examples of these initiatives have been specified by the proponents on a number of the reviewed projects $(\mathrm{BC}$ EAO 2014c; BC MARR 2015a,c). It is worthwhile noting that there is no legal obligation for proponents to provide capacity funding to Indigenous 
groups as part of the consultation process. Nevertheless, proponents often chose to provide funding to help inform the consultation process and to avoid potential impacts to Aboriginal interests from the proposed project. These types of agreements should not be confused with any economic benefit agreements (BC EAO 2013e).

\section{Economic benefit agreements}

Examples of economic benefit agreements with Indigenous peoples include but are not limited to:

- The Natural Gas Pipeline Benefits Agreements that are currently reached with 29 out of 32 eligible First Nations for four major natural gas pipelines, the Prince Rupert Gas Transmission, Coastal GasLink, Westcoast Connector Gas Transmission and Pacific Trail Pipeline (totaling in 62 agreements) (BC MARR 2015c, 2016e).

- The First Nations Limited Partnership Agreement which is unique among any pipeline agreements in Western Canada, since the Pacific Trail Pipeline Project is the first proposed natural gas pipeline related to $\mathrm{LNG}$ in $\mathrm{BC}$ with the support of all 16 directly affected First Nations (BC MARR 2015c; Chevron Canada 2016; FNLP 2016).

- The Coastal First Nations LNG Benefits Agreement signed by nine Coastal First Nations for ten proposed LNG projects to share in the benefits associated with the development of an LNG industry on the north coast of British Columbia (BC MARR and GBI Society 2016).

- Impact benefits agreements, including agreements with four of five Indigenous groups potentially affected by the Pacific NorthWest LNG project and four economic benefit agreements on natural gas exploration, development and production between the Province and the Treaty 8 First Nations (Hoekstra 2016; Province of BC 2014b).

- Revenue sharing agreements, for example, with Lax Kw'alaams and Metlakatla First Nations that share a portion of Provincial Government revenues from sole proponent agreements related to the Grassy Point lands and the proponents Aurora LNG (Aurora LNG Digby Island Project) and Woodside Energy (Grassy Point LNG Project), and so on (Province of BC 2014b).

It should be noted that economic benefits agreements are not legally required and must be kept separate and distinct from the duty to consult. By entering into impact benefits agreements, Indigenous peoples are not waiving their right to review, comment and approve or not, any 
environmental studies, permit applications or environmental monitoring regimes related to the project (McCarthy Tétrault LLP 2016; McMillan LLP 2011).

\section{CONCLUSIONS}

This chapter has reviewed a substantial amount of information on the major environmental and Indigenous peoples issues arising from natural gas and LNG development in British Columbia and the key approaches to address these issues.

A regulatory framework for the natural gas and LNG industry in BC is robust, with many layers of government policies and regulations to guide responsible development of this sector. While the provincial and federal regulatory authorities work toward harmonization of the EA processes in order to avoid duplication of efforts and to clarify roles and responsibilities, these two regimes remain distinct and somewhat complex. It is very important for the proponents of the natural gas pipeline and LNG projects in $\mathrm{BC}$ to fully understand the provincial and federal EA processes in order to manage time frames and costs for the proposed projects where possible and to build effective relationships with stakeholders, Indigenous groups and the general public.

The review of the EA applications for 29 major natural gas, NGL and LNG projects in British Columbia that have undergone a typical EA process (active or complete) with the provincial and/or federal responsible authority since 2010 identified the following key environmental issues:

- Significant residual adverse effects related to GHG emissions.

- Significant residual adverse effects and cumulative effects to rare and threatened wildlife species (specifically, to caribou, grizzly bear and harbour porpoise).

- Cumulative adverse impacts of natural gas development.

Significant residual adverse effects related to $\mathrm{GHG}$ emissions have been reported on seven projects out of 18 where the provincial or federal EA has been completed. Significant residual adverse effects on caribou and caribou habitat were determined on three major natural gas pipeline projects out of 18 with the EA process completed, and were also determined as a key issue that should be fully compensated for on two other natural gas pipeline projects. The analysis of EA reports for six provincially and/or federally approved natural gas pipeline and LNG projects that include the marine resources VCs revealed impacts to marine mammals to be a 
concern for several projects. The residual adverse effects and cumulative adverse effects on marine mammals (particularly, on harbour porpoise) were considered to be significant for one LNG project.

There is a growing concern about the cumulative impacts of natural gas development arising from both stakeholders and the general public. For two reviewed projects, impacts to threatened wildlife species (caribou and grizzly bear) were considered as significant in terms of cumulative effects, but not in terms of project specific effects. These cumulative impacts will only become more significant with the increased intensity of natural gas and LNG development.

Cumulative impacts are also of particular concern for Indigenous groups, with many of them unsatisfied with the adequacy of cumulative effects assessment of past, present and reasonably foreseeable industrial activity in their traditional territory, in relation to their respective Aboriginal interests. Other the most common potential adverse impacts on Aboriginal interests summarized in this chapter include but are not limited to effects on health and socio-economic conditions; physical and cultural heritage; the current use of lands and resources for traditional purposes; and sites of historical or archeological significance.

Main approaches to mitigate the identified environmental issues include various types of mitigation measures (specified as legally binding conditions of the EAC, EADS or CPCN) to avoid, minimize, restore on-site or offset potential adverse effects. Pipeline route changes to avoid or decrease potential adverse effects can also be proposed as project design restrictions. In order to implement mitigation measures and best management practices, EMPs and follow-up programs would be required for all phases of proposed projects. They are usually developed by proponents in consultation with appropriate regulatory agencies, Indigenous groups and key stakeholders. In addition, the Province of $\mathrm{BC}$ has proposed, designed and implemented a number of key strategies, progressive programs and policies to reduce potential adverse effects of industrial development on the environmental VCs.

Understanding of Aboriginal and treaty legal rights issues is fundamental to the potential success of proposed natural gas pipeline and LNG projects in British Columbia. A failure to understand these issues can affect the progress or even the regulatory approval of a proposed project. While the duty to consult Indigenous groups rests with the Crown, the regulatory authorities can assign certain procedural aspects of consultation to proponents. Industry must contact, involve and reach agreements with Indigenous peoples prior to commencing any operations in their traditional lands. The engagement of Indigenous peoples by proponents needs to start as early as possible, prior to the exploration phase and 
continue throughout the lifecycle of the project, including construction, operations, decommissioning and abandonment.

The Crown's duty to consult and accommodate relates to avoiding or mitigating impacts on Aboriginal rights or title and does not imply an obligation to enter into any form of economic benefits agreement with Indigenous groups. Nevertheless, signing such agreements can build effective relations with Indigenous groups potentially affected by a proposed project. The importance of achieving and maintaining positive relationships, effective consultation and engagement with potentially affected Indigenous groups cannot be stressed enough and is one of the most critical factors for the success of the project.

\section{NOTES}

* The information presented in this chapter is based on the comprehensive study Risk Analysis of British Columbia Natural Gas Projects: Environmental and Indigenous Peoples Issues conducted by the authors on behalf of the Canadian Energy Research Institute. The Canadian Energy Research Institute is an independent, not-for-profit research establishment created through a partnership of industry, academia and government in 1975.

The authors are grateful for the helpful insights received from Miles Scott-Brown (Integrated Environments Ltd.) and Dr Stella Swanson (Swanson Environmental Strategies).

1. The Pacific Trail Pipelines project was previously known as the Kitimat-Summit Lake Pipeline Looping project.

2. The term Indigenous peoples is increasingly replacing Aboriginal peoples, since the United Nations Declaration on Indigenous Peoples (2007), even though the term Aboriginal peoples still prevails in Canadian legislation. The term Indigenous peoples is generally considered to be more inclusive and respectful. For the purposes of this chapter, the authors will use the terms "Aboriginal peoples" and "Indigenous peoples" interchangeably, dependent on provincial versus federal legislation.

3. For the purposes of this chapter, the authors will use the term "First Nation(s)," unless referring to a document or event where the term "Indian" was used.

\section{REFERENCES}

AltaGas Ltd. (2016), "Ridley Island propane export terminal environmental evaluation document," accessed 9 January 2017 at https://www.altagas.ca/our-infrastructure/projects/ ridley-island-propane-export-terminal.

BC EAO (British Columbia Environmental Assessment Office) (2008), "Kitimat-Summit Lake Pipeline Looping Project assessment report," accessed 22 September 2016 at http:// a100.gov.bc.ca/appsdata/epic/html/deploy/epic_project_home_270.html.

BC EAO (2009), "Cabin Gas Plant Project assessment report," accessed 21 September 2016 at http://a100.gov.bc.ca/appsdata/epic/html/deploy/epic_project_home_341.html.

BC EAO (2011), "Extension order issued under Section 18 of the Environmental Assessment Act and an Application to Extend Environmental Assessment Certificate E06-01 for the Kitimat Liquefied Natural Gas Terminal Project," accessed 26 September 2016 at http:// a100.gov.bc.ca/appsdata/epic/html/deploy/epic_project_home_244.html. 
BC EAO (2013a), "Memorandum of understanding between the Canadian Environmental Assessment Agency and the British Columbia Environmental Assessment Office on Substitution of Environmental Assessments," accessed 24 October 2016 at http://www.eao. gov.bc.ca/pdf/EAO_CEAA_Substitution_MOU.pdf.

BC EAO (2013b), "Extension Order Issued under Section 18 of the Environmental Assessment Act and an Application to Extend Environmental Assessment Certificate E08-01 for the Pacific Trail Pipelines Project," accessed 26 September 2016 at http://a100. gov.bc.ca/appsdata/epic/html/deploy/epic_project_home_270.html.

BC EAO (2013c), "Fortune Creek Gas Project assessment report," accessed 22 September 2016 at http://a100.gov.bc.ca/appsdata/epic/html/deploy/epic_project_home_379.html.

BC EAO (2013d), "Guideline for the selection of valued components and assessment of potential effects," accessed 6 October 2016 at http://www.eao.gov.bc.ca/pdf/EAO_Valued_ Components_Guideline_2013_09_09.pdf.

BC EAO (2013e), "Guide to involving proponents when consulting First Nations in the environmental assessment process," accessed 6 October 2016 at http://www2.gov.bc.ca/ gov/content/environment/natural-resource-stewardship/consulting-with-first-nations.

BC EAO (2013f), "Schedule B. Documentation and correspondence considered by the environmental assessment office: Dawson Liquids Extraction Project," accessed 20 September 2016 at http://a100.gov.bc.ca/appsdata/epic/html/deploy/epic_project_home_399.html.

BCEAO(2014a), "Coastal GasLink Pipeline Project assessment report," accessed 21 September 2016 at http://a100.gov.bc.ca/appsdata/epic/html/deploy/epic_project_home_392.html.

BC EAO (2014b), "Westcoast Connector Gas Transmission Project assessment report," accessed 22 September 2016 at http://a100.gov.bc.ca/appsdata/epic/html/deploy/epic_proje ct_home_385.html.

BC EAO (2014c), "Pacific Northwest LNG Project assessment report," accessed 22 September 2016 at http://a100.gov.bc.ca/appsdata/epic/html/deploy/epic_project_home_396.html.

BC EAO (2014d), "Prince Rupert Gas Transmission Project assessment report," accessed 21 September 2016 at http://a100.gov.bc.ca/appsdata/epic/html/deploy/epic_project_home_4 03.html.

BC EAO (2015a), "Environmental Assessment Office user guide: An overview of environmental assessment in British Columbia," accessed 17 October 2016 at http://www.eao.gov. bc.ca/pdf/EAO_User_Guide_20150629.pdf.

BC EAO (2015b), "LNG Canada Export Terminal Project assessment report," accessed 21 September 2016 at http://a100.gov.bc.ca/appsdata/epic/html/deploy/epic_project_home_3 98.html.

BC EAO (2015c), "Fact sheet: Substitution of environmental assessments in British Columbia," accessed 22 September 2016 at http://www.eao.gov.bc.ca/pdf/Fact_Sheet_LN G\%20Canada\%20Substitution_17JUN15.pdf.

BC EAO (2015d), "Summary of evaluation for the proposed Saturn 15-27 Sweet Gas Plant Project," accessed 20 September 2016 at http://a100.gov.bc.ca/appsdata/epic/html/deploy/ epic_project_home_434.html.

BC EAO (2015e), "Woodfibre LNG Project assessment report," accessed 21 September 2016 at http://a100.gov.bc.ca/appsdata/epic/html/deploy/epic_project_home_408.html.

BC EAO (2016a), "Environmental assessment process," accessed 19 October 2016 at http:// www.eao.gov.bc.ca/ea_process.html.

BC EAO (2016b), "Project Information Centre (E-PIC) - Project detail report," accessed 29 September 2016 at http://a100.gov.bc.ca/appsdata/epic/html/deploy/epic_project_detail_ report.html.

BC EAO (2016c), “Amendment \#4 to the Certificate \#E08-01 for the Pacific Trail Pipelines Project,” accessed 21 September 2016 at http://a100.gov.bc.ca/appsdata/epic/html/deploy/ epic_project_home_270.html.

BC EAO (2016d), "Northeast British Columbia Expansion Project assessment report," accessed 22 September 2016 at http://a100.gov.bc.ca/appsdata/epic/html/deploy/epic_pro ject_home_433.html.

BC EAO (2016e), "Eagle Mountain - Woodfibre Gas Pipeline Project assessment report," 
accessed 22 September 2016 at http://a100.gov.bc.ca/appsdata/epic/html/deploy/epic_ project_home_406.html.

BC EAO, Transport Canada, Environment Canada and Indigenous and Northern Affairs Canada (2006), "Kitimat LNG Terminal Project assessment report," accessed 26 September 2016 at http://a100.gov.bc.ca/appsdata/epic/html/deploy/epic_project_home_244.html.

BC MARR (British Columbia Ministry of Aboriginal Relations and Reconciliation) (2014a), "Guide to involving proponents when consulting First Nations," accessed 6 October 2016 at http://www2.gov.bc.ca/gov/content/environment/natural-resource-stewardship/ consulting-with-first-nations.

BC MARR (2014b), "B.C. to engage with First Nations, industry on eco-stewardship," BC Government News, 23 May, accessed 31 October 2016 at https://news.gov.bc.ca/stories/ bc-to-engage-with-first-nations-industry-on-eco-stewardship.

BC MARR (2015a), "B.C. boosts investment in Aboriginal skills training," BC Government News, 24 April, accessed 30 October 2016 at https://news.gov.bc.ca/stories/ bc-boosts-investment-in-aboriginal-skills-training.

BCMARR (2015b), "Funding supports LNG environmental legacies,"BC Government News, 29 July, accessed 31 October 2016 at https://news.gov.bc.ca/releases/2015ARR0032-001206.

BC MARR (2015c), "Factsheet: Partnering with First Nations on LNG development," BC Government News, 14 December, accessed 30 October 2016 at https://news.gov.bc.ca/ factsheets/partnering-with-first-nations-on-lng-development.

BC MARR (2016a), "Consulting with First Nations - Province of British Columbia," accessed 6 October 2016 at http://www2.gov.bc.ca/gov/content/environment/natural-resou rce-stewardship/consulting-with-first-nations.

BC MARR (2016b), "First Nations in treaty process - Province of British Columbia," accessed 6 October 2016 at http://www2.gov.bc.ca/gov/content/environment/naturalresource-stewardship/consulting-with-first-nations/first-nations-negotiations/first-natio ns-in-treaty-process.

BC MARR (2016c), "First Nations negotiations," accessed 24 October 2016 at http:// www2.gov.bc.ca/gov/content/environment/natural-resource-stewardship/consulting-withfirst-nations/first-nations-negotiations.

BC MARR (2016d), "Liquefied Natural Gas environmental stewardship initiative - Province of British Columbia," accessed 30 October 2016 at http://www2.gov.bc.ca/gov/content/ environment/natural-resource-stewardship/consulting-with-first-nations/liquefied-natur al-gas-environmental-stewardship-initiative.

BC MARR (2016e), "Natural Gas Pipeline benefits agreements - Province of British Columbia," accessed 21 September 2016 at http://www2.gov.bc.ca/gov/content/environme nt/natural-resource-stewardship/consulting-with-first-nations/first-nations-negotiations/ natural-gas-pipeline-benefits-agreements.

BC MARR (2016f), "Treaty 8 First Nations - Province of British Columbia," accessed 6 October 2016 at http://www2.gov.bc.ca/gov/content/environment/natural-resource-steward ship/consulting-with-first-nations/first-nations-negotiations/first-nations-a-z-listing/tre aty-8-first-nations.

BC MARR and GBI Society (2016), "Coastal First Nations Liquefied Natural Gas benefits agreement between Great Bear Initiative Society and British Columbia," accessed 20 September 2016 at http://www2.gov.bc.ca/assets/gov/environment/natural-resourcestewardship/consulting-with-first-nations/agreements/cfn_lng_signed_jan_2016.pdf.

BC MEM (British Columbia Ministry of Energy and Mines) (2012), "British Columbia's natural gas strategy. Fuelling B.C.'s economy for the next decade and beyond," accessed 7 October 2016 at http://www2.gov.bc.ca/assets/gov/farming-natural-resources-andindustry/natural-gas-oil/strategy_natural_gas.pdf.

BC MFLNRO (British Columbia Ministry of Forests, Lands and Natural Resource Operations) and BC MEM (2016), "Cumulative effects framework - Province of British Columbia," accessed 17 October 2016 at http://www2.gov.bc.ca/gov/content/environment/ natural-resource-stewardship/cumulative-effects-framework.

BC MOE (British Columbia Ministry of Environment) (n.d.), "Boreal Caribou management 
in BC," accessed 28 September 2016 at http://www2.gov.bc.ca/gov/content/environment/ plants-animals-ecosystems/wildlife/wildlife-conservation/caribou/boreal-caribou.

BC MOE (2010), "Information bulletin. Cabin Gas Plant Project approved," accessed 21 September 2016 at http://a100.gov.bc.ca/appsdata/epic/html/deploy/epic_project_home_341. html.

BC MOE (2011), "Implementation plan for the ongoing management of Boreal Caribou (Rangifer tarandus caribou pop. 14) in British Columbia," Victoria, BC.

BC MOE (2014a), "Mountain caribou recovery in BC," accessed 28 October 2016 at http:// www.env.gov.bc.ca/wld/speciesconservation $/ \mathrm{mc} /$.

BC MOE (2014b), "Procedures for mitigating impacts on environmental values (environmental mitigation procedures). Version 1.0," accessed 6 October 2016 at http://www.env. gov.bc.ca/emop/docs/EM_Procedures_May27_2014.pdf.

BC MOE (2016a), "Caribou in British Columbia," accessed 16 October 2016 at http://www. env.gov.bc.ca/wld/speciesconservation/.

BC MOE (2016b), "Climate action legislation - Province of British Columbia," accessed 28 October 2016 at http://www2.gov.bc.ca/gov/content/environment/climate-change/poli cy-legislation-programs/climate-action-legislation\#cngreg.

BC MOE and BC MEMPR (British Columbia Ministry of Energy, Mines and Petroleum Resources) (2006), "Environmental assessment certificate \#E06-01 for the Kitimat Liquefied Natural Gas Terminal Project," accessed 21 September 2016 at http://a100.gov. bc.ca/appsdata/epic/html/deploy/epic_project_home_244.html.

BC MOE and BC MEMPR (2008), "Environmental assessment certificate \#E08-01 for the Kitimat-Summit Lake Pipeline Looping Project," accessed 21 September 2016 at http:// a100.gov.bc.ca/appsdata/epic/html/deploy/epic_project_home_270.html.

BC MOE and BC MEMPR (2010), "Environmental assessment certificate \#E09-06 for the Cabin Gas Plant Project,” accessed 21 September 2016 at http://a100.gov.bc.ca/appsdata/ epic/html/deploy/epic_project_home_341.html.

BC MOE and BC MNGD (British Columbia Ministry of Natural Gas Development) (2013a), "Fortune Creek Gas Plant. Schedule B. Table of conditions for an environmental assessment certificate," accessed 22 September 2016 at http://a100.gov.bc.ca/appsdata/ epic/html/deploy/epic_project_home_379.html.

BC MOE and BC MNGD (2013b), "Environmental assessment certificate \# E13-03 for the Fortune Creek Gas Project," accessed 22 September 2016 at http://a100.gov.bc.ca/ appsdata/epic/html/deploy/epic_project_home_379.html.

BC MOE and BC MNGD (2014a), "Coastal GasLink Pipeline Project. Schedule B. Table of conditions for an environmental assessment certificate," accessed 21 September 2016 at http://a100.gov.bc.ca/appsdata/epic/html/deploy/epic_project_home_392.html.

BC MOE and BC MNGD (2014b), "Environmental assessment certificate \#E14-03 for the Coastal GasLink Pipeline Project," accessed 21 September 2016 at http://a100.gov.bc.ca/ appsdata/epic/html/deploy/epic_project_home_392.html.

BC MOE and BC MNGD (2014c), "Pacific Northwest LNG Project. Schedule B. Table of conditions for an environmental assessment certificate," accessed 21 September 2016 at http://a100.gov.bc.ca/appsdata/epic/html/deploy/epic_project_home_396.html.

BC MOE and BC MNGD (2014d), "Environmental assessment certificate \#E14-04 for the Pacific Northwest LNG Project," accessed 21 September 2016 at http://a100.gov.bc.ca/ appsdata/epic/html/deploy/epic_project_home_396.html.

BC MOE and BC MNGD (2014e), "Environmental assessment certificate \#E14-05 for the Westcoast Connector Gas Transmission Project," accessed 22 September 2016 at http:// a100.gov.bc.ca/appsdata/epic/html/deploy/epic_project_home_385.html.

BC MOE and BC MNGD (2014f), "Environmental assessment certificate \#E14-06 for the Prince Rupert Gas Transmission Project," accessed 22 September 2016 at http://a100.gov. bc.ca/appsdata/epic/html/deploy/epic_project_home_403.html.

BC MOE and BC MNGD (2014g), "Prince Rupert Gas Transmission Project. Schedule B. Table of conditions for an environmental assessment certificate," accessed 21 September 2016 at http://a100.gov.bc.ca/appsdata/epic/html/deploy/epic_project_home_403.html. 
BC MOE and BC MNGD (2014h), "Westcoast Connector Gas Transmission Project. Schedule B. Table of conditions for an environmental assessment certificate," accessed 21 September 2016 at http://a100.gov.bc.ca/appsdata/epic/html/deploy/epic_project_home_ 385.html.

BC MOE and BC MNGD (2015a), "Environmental assessment certificate \#E15-01 for the LNG Canada Export Terminal Project," accessed 22 September 2016 at http://a100.gov. bc.ca/appsdata/epic/html/deploy/epic_project_home_398.html.

BC MOE and BC MNGD (2015b), "LNG Canada Export Terminal Project. Schedule B. Table of conditions for an environmental assessment certificate," accessed 22 September 2016 at http://a100.gov.bc.ca/appsdata/epic/html/deploy/epic_project_home_398.html.

BC MOE and BC MNGD (2015c), "Environmental assessment certificate \#E15-02 for the Woodfibre LNG Project,” accessed 22 September 2016 at http://a100.gov.bc.ca/appsdata/ epic/html/deploy/epic_project_home_408.html.

BC MOE and BC MNGD (2015d), "Woodfibre LNG Project. Schedule B. Table of conditions for an environmental assessment certificate," accessed 21 September 2016 at http:// a100.gov.bc.ca/appsdata/epic/html/deploy/epic_project_home_408.html.

BC MOE and BC MNGD (2016a), "Eagle Mountain - Woodfibre Gas Pipeline Project. Schedule B. Table of conditions for an environmental assessment certificate," accessed 21 September 2016 at http://a100.gov.bc.ca/appsdata/epic/html/deploy/epic_project_home_4 06.html.

BC MOE and BC MNGD (2016b), "Northeast British Columbia Expansion Project. Schedule B. Table of conditions for an environmental assessment certificate," accessed 21 September 2016 at http://a100.gov.bc.ca/appsdata/epic/html/deploy/epic_project_home_433.html.

BC MOE and BC MNGD (2016c), "Environmental assessment certificate \#E16-01 for the Eagle Mountain - Woodfibre Gas Pipeline Project," accessed 22 September 2016 at http:// a100.gov.bc.ca/appsdata/epic/html/deploy/epic_project_home_406.html.

BC MOE and BC MNGD (2016d), "Environmental assessment certificate \#E16-02 for the Northeast British Columbia Expansion Project," accessed 22 September 2016 at http:// a100.gov.bc.ca/appsdata/epic/html/deploy/epic_project_home_433.html.

BC OGC (British Columbia Oil and Gas Commission) (2015a), "Hydrocarbon and byproduct reserves in British Columbia," accessed 3 November 2016 at https://www.bcogc. ca/node/12952/download.

BC OGC (2015b), "NorthEast water tool," accessed 9 January 2017 at https://water.bcogc. $\mathrm{ca} /$ newt.

BC OGC (2015c), "Defining: LNG \& major projects," accessed 23 October 2016 at http:// www.bcogc.ca/node/11415/download.

BC OGC (2015d), "Industry bulletin 2015-20. Area-based analysis required in application process," accessed 28 October 2016 at http://www.bcogc.ca/node/12694/download.

BC Treaty Commission (1999), "A lay person's guide to Delgamuukw," accessed 9 October 2016 at http://www.bctreaty.net/sites/default/files/delgamuukw.pdf.

BC Treaty Commission (2008), "Why treaties? A legal perspective," accessed 9 October 2016 at http://www.bctreaty.net/sites/default/files/why_treaties_update_Aug08.pdf.

BC Treaty Commission (2016), "Negotiation update: BC Treaty Commission," accessed 9 January 2017 at http://www.bctreaty.net/negotiation-update.

BCSC (Supreme Court of British Columbia) (2016), Coastal First Nations v. British Columbia (Environment) - 2016 BCSC 34. Supreme Court of British Columbia.

Canada (2012), "Regulations Designating Physical Activities SOR/2012-147," accessed 23 October 2016 at http://laws-lois.justice.gc.ca/PDF/SOR-2012-147.pdf.

Canada and NEB (National Energy Board) (2010), "Reasons for decision in the matter of NOVA Gas Transmission Ltd.: Application dated 30 April 2009 for the Groundbirch Pipeline Project," Calgary, Alberta: National Energy Board.

Canada and NEB (2012), "Reasons for decision in the matter of NOVA Gas Transmission Ltd.: Application dated 29 April 2011 for the Northwest Mainline expansion," Calgary, Alberta: National Energy Board.

Canada and NEB (2013), "National Energy Board report in the matter of NOVA Gas 
Transmission Ltd.: Application dated 14 October 2011 for the Northwest Mainline Komie North extension. GH-001-2012," Calgary, Alberta: National Energy Board.

Canada and NEB (2015), "National Energy Board report in the matter of Nova Gas Transmission Ltd. Application dated 8 November 2013 for the North Montney Mainline Project: GH-001-2014," Calgary, Alberta: National Energy Board.

Canada and NEB (2016), "National Energy Board report in the matter of NOVA Gas Transmission Ltd. Application dated 2 September 2015 for the Towerbirch Expansion Project. GH-003-2015," Calgary, Alberta: National Energy Board.

Canadian Press (2015), “Tsawwassen First Nation rejects proposed LNG facility," Vancouver Sun, 17 December.

CAPP (Canadian Association of Petroleum Producers) (2016), Statistical Handbook for Canada's Upstream Petroleum Industry, Calgary, Canada.

CEAA (Canadian Environmental Assessment Agency) (2013), "Environmental impact statement guidelines," accessed 6 October 2016 at https://www.ceaa-acee.gc.ca/050/documents/ p80019/87455E.pdf.

CEAA (2015a), "Assessing cumulative environmental effects under the Canadian Environmental Assessment Act, 2012," Ottawa, Canada.

CEAA (2015b), "Ministerial statement. Government of Canada's decision on the environmental assessment of the LNG Canada Export Terminal Project," June 17, accessed 26 September 2016 at http://www.ceaa-acee.gc.ca/050/document-eng.cfm?document=101849.

CEAA (2016a), "Basics of environmental assessment," accessed 22 September 2016 at https:// www.canada.ca/en/environmental-assessment-agency/services/environmental-assessme nts/basics-environmental-assessment.html.

CEAA (2016b), "Pacific NorthWest LNG Project Environmental Assessment Report," accessed 28 September 2016 at http://www.ceaa.gc.ca/050/documents/p80032/115668E. pdf.

CERI (Canadian Energy Research Institute) (2016), "Canadian natural gas market review. Study No. 158," accessed 3 November 2016 at http://resources.ceri.ca/PDF/Pubs/Studies/ Study_158_Full_Report.pdf.

Chevron Canada (2016), "Pacific Trail Pipeline," accessed 26 September 2016 at http://www. chevron.ca/our-businesses/kitimat-lng-project/pacific-trail-pipeline.

DFO (Department of Fisheries and Oceans Canada) (2009), "Management plan for the Pacific harbour porpoise (Phocoena phocoena) in Canada. Species at Risk Act Management Plan Series," Ottawa, Canada: Fisheries and Oceans Canada.

Environmental Reporting BC and BC MOE (2012), "Grizzly bear population status in BC (2012)," accessed 29 September 2016 at http://www.env.gov.bc.ca/soe/indicators/ plants-and-animals/print_ver/2012_Grizzly_Bear_Population_Status_BC.pdf.

FNLP (First Nations Limited Partnership) (2016), "First Nations Limited Partnership," accessed 26 September 2016 at http://bcfnlp.ca/.

Government of BC (2011), "Interim operating practices for oil and gas activities in identified boreal caribou habitat in British Columbia," accessed 25 October 2016 at http://www.env. gov.bc.ca/wld/speciesconservation/bc/documents/Operating\%20Practices.pdf.

Government of Canada (2013), "National inventory report: Greenhouse gas sources and sinks in Canada - Government of Canada Publications," accessed 8 November 2016 at http:// www.publications.gc.ca/site/eng/9.506002/publication.html.

Government of Canada (2015), "Intended nationally determined contribution: Canada's INDC submission to the UNFCCC," accessed 17 October 2016 at http://www4.unfccc.int/submis sions/INDC/Published $\% 20$ Documents/Canada/1/INDC $\% 20-\% 20$ Canada $\% 20-\% 20$ English. pdf.

Government of Canada (2016a), "Statement. Government of Canada moves to restore trust in environmental assessment," Government of Canada News, 27 January, accessed 27 September 2016 at http://news.gc.ca/web/.

Government of Canada (2016b), "News release. The Government of Canada approves Pacific NorthWest LNG Project," Government of Canada News, 27 September, accessed 27 September 2016 at http://news.gc.ca/web/. 
Government of Canada and NEB (2016), "NEB - Applications \& filings," accessed 24 October 2016 at https://www.neb-one.gc.ca/pplctnflng/index-eng.html.

Hoekstra, G. (2016), "First Nation support for Pacific NorthWest LNG growing," Vancouver Sun, 29 April.

INAC (Indigenous and Northern Affairs Canada) (2010a), "About British Columbia First Nations," accessed 28 September 2016 at https://www.aadnc-aandc.gc.ca/eng/.

INAC (2010b), "The Nisga'a final agreement in the Canadian context," accessed 11 October 2016 at http://www.aadnc-aandc.gc.ca/eng/.

INAC (2016a), "Treaty negotiations in British Columbia," accessed 28 September 2016 at https://www.aadnc-aandc.gc.ca/DAM/DAM-INTER-BC/STAGING/texte-text/trynega_11 00100021019_eng.pdf.

INAC (2016b), "Métis rights," accessed 9 October 2016 at http://www.aadnc-aandc.gc.ca/ eng/.

Jang, B. (2017), "Two Gitxsan chiefs seek to block Pacific NorthWest LNG terminal construction," The Globe and Mail, 10 January.

McCarthy Tétrault LLP (2016), "Liquefied Natural Gas (LNG) Regulation in British Columbia. August 2016," accessed 7 October 2016 at https://www.mccarthy.ca/pubs/ LNG_Regulation_in_BC_(August_2016).pdf.

McMillan LLP (2011), "Seven steps for navigating the environmental assessment process in British Columbia," accessed 31 October 2016 at http://www.mcmillan.ca/Files/143329_ seven $\% 20$ steps $\% 20$ for $\% 20$ navigating $\% 20$ the $\% 20$ environmental $\% 20$ assessment $\% 20$ proc ess $\% 20 \mathrm{in} \% 20$ British $\% 20$ Columbia.pdf.

MOE (Ministry of Environment Canada) (2016), "Decision statement issued under Section 54 of the Canadian Environmental Assessment Act, 2012 for the Pacific NorthWest LNG Project," accessed 28 September 2016 at http://www.ceaa.gc.ca/050/documents/ p80032/115669E.pdf.

NEB (National Energy Board) (2010), "Order XG-W102-07-2010 for the Fort Nelson North Processing Facility Project,” accessed 22 September 2016 at https://apps.neb-one.gc.ca/ REGDOCS/Item/View/565873.

NEB (2011), "Reasons for decisions in the matter of NOVA Gas Transmission Ltd. application dated 19 February 2010 for the Horn River Project GH-2-2010," accessed 16 October 2016 at https://apps.neb-one.gc.ca/REGDOCS/Item/View/601085.

NEB (2012), "Draft environmental screening report for the Northwest Mainline expansion pursuant to the Canadian Environmental Assessment Act (CEA Act). Northwest Mainline Expansion," accessed 26 October 2016 at https://apps.neb-one.gc.ca/REGDOCS/Item/ View/685859.

NEB (2015a), "Certificate of Public Convenience and Necessity GC-125 for the North Montney Mainline Project," accessed 22 September 2016 at http://www.ceaa-acee.gc.ca/05 0/documents/p80057/101998E.pdf.

NEB (2015b), “ARCHIVED - NOVA Gas Transmission Ltd. - Horn River Project - GH-22010,” accessed 28 September 2016 at http:/www.neb-one.gc.ca/pplctnflng/mjrpp/archive/ hrnrvr/nvgshrnrvr-eng.html.

NEB (2015c), "ARCHIVED - NOVA Gas Transmission Ltd. - Northwest Mainline Expansion - GH-2-2011," accessed 27 September 2016 at http://www.neb-one.gc.ca/ pplctnflng/mjrpp/archive/nrthwstmnlnxpnsn/nrthwstmnlnxpnsn-eng.html.

NEB (2015d), "ARCHIVED - NOVA Gas Transmission Ltd. (NGTL) - Groundbirch Pipeline Project - GH-1-2009," accessed 28 September 2016 http://www.neb-one.gc.ca/ppl ctnflng/mjrpp/archive/grndbrch/grndbrch-eng.html.

NEB (2016), "Summary of recommendation. NGTL Towerbirch Expansion Project," accessed 7 October 2016 at http://www.neb-one.gc.ca/pplctnflng/mjrpp/twrbrch/twrbrch-eng.pdf.

Nexen Energy ULC (2015), “Application information requirements and valued components selection document for the proposed Aurora LNG Project at Digby Island," accessed 27 September 2016 at http://a100.gov.bc.ca/appsdata/epic/html/deploy/epic_project_home_4 16.html.

Olynyk, John M. (2005), "The Haida Nation and Taku River Tlingit decisions: Clarifying 
roles and responsibilities for Aboriginal consultation and accommodation," accessed 11 October 2016 at http://www.lawsonlundell.com/media/news/236_Negotiatorarticle.pdf.

Pacific Northern Gas Ltd. (2014), "Application information requirements for the Pacific Northern Gas Looping Project," accessed 6 September 2016 at http://a100.gov.bc.ca/ appsdata/epic/html/deploy/epic_project_home_405.html.

Prince Rupert LNG Limited (2014), "Application information requirements for the Prince Rupert LNG," accessed 6 September 2016 at http://a100.gov.bc.ca/appsdata/epic/html/ deploy/epic_project_home_402.html.

Province of BC (n.d.), "Building relationships with First Nations: Respecting rights and doing good business," accessed 29 October 2016 at http://www2.gov.bc.ca/gov/content/ environment/natural-resource-stewardship/consulting-with-first-nations.

Province of BC (2002), "Reviewable projects regulation, BC Reg 370/2002," accessed 23 October 2016 at http://www.bclaws.ca/civix/document/id/loo79/loo79/13_370_2002.

Province of BC (2008), "Climate action plan," accessed 17 October 2016 at http://www.gov. bc.ca/premier/attachments/climate_action_plan.pdf.

Province of BC (2010), "Updated procedures for meeting legal obligations when consulting First Nations. Interim," accessed 6 October 2016 at http://www2.gov.bc.ca/gov/content/ environment/natural-resource-stewardship/consulting-with-first-nations.

Province of BC (2014a), "Addressing cumulative effects in natural resource decision-making: A framework for success," accessed 17 October 2016 at http://www2.gov.bc.ca/gov/conte nt/environment/natural-resource-stewardship/cumulative-effects-framework.

Province of BC (2014b), "B.C. and First Nations sign first LNG revenue-sharing agreements," BC Government News, 9 April, accessed 31 October 2016 at https://news.gov.bc.ca/stori es/bc-and-first-nations-sign-first-lng-revenue-sharing-agreements.

Province of BC (2015), "Northeast water strategy," accessed 28 October 2016 at http://www2. gov.bc.ca/assets/gov/environment/air-land-water/water/northeast-water-strategy/2015-no rtheast-water-strategy.pdf.

Province of BC (2016a), "B.C. LNG projects - LNG in BC," accessed 24 October 2016 at http://lnginbc.gov.bc.ca/tile/bc-lng-projects/.

Province of BC (2016b), "Climate leadership plan," accessed 17 October 2016 at https:// climate.gov.bc.ca/app/uploads/sites/13/2016/10/4030_CLP_Booklet_web.pdf.

Province of BC (2016c), "Edition: LNG environmental stewardship initiative," BC Government News, accessed 28 October 2016 at https://news.gov.bc.ca/newsletters/ lng-environmental-stewardship-initiative/lng-environmental-stewardship-initiative/regi onal-highlights.

Pynn, L. (2016), "First Nations overwhelmingly support LNG, B.C. minister asserts," Vancouver Sun, 7 June.

RCAP (Royal Commission on Aboriginal People) (1996), "Perspectives and realities: Métis perspectives," in Report of the Royal Commission on Aboriginal People, vol. 4., accessed 12 October 2016 at http://caid.ca/RRCAP4.5.pdf.

Robe, K.B. and P.A. Dean (2016), "Case Comment: Coastal First Nations v. British Columbia (Environment), 2016 BCSC 34," accessed 11 October 2016 at http://www.mondaq.com/ canada/x/511790/Oil+Gas+Electricity/Case+Comment+Coastal+First+Nations+v+Briti sh+Columbia+Environment+2016+BCSC+34.

Salmo Consulting Inc. and Diversified Environmental Services (2003), "Cumulative effects indicators, thresholds and case studies: Volume 2," accessed 18 October 2016 at https:// www.alces.ca/projects/download/242/CEAMF-Final-Report2.pdf.

SCC (Supreme Court of Canada) (1973), "Calder et al. v. Attorney-General of British Columbia," 1973 S.C.R. 313.

SCC (1990), "Her Majesty the Queen v. Ronald Edward Sparrow," 1990 1 S.C.R 1075.

SCC (1997), "Delgamuukw v. British Columbia," 1997 S S.C.R. 1010.

SCC (2003), "Her Majesty the Queen v. Steve Powley and Roddy Charles Powley," 2003 SCC 43.

SCC (2004a), "Haida Nation v. British Columbia (Minister of Forests)," 2004 SCC 73.

SCC (2004b), "Taku River Tlingit First Nation v. British Columbia (Project Assessment Director)," 2004 SCC 74. 


\section{Handbook of energy politics}

SCC (2005), "Mikisew Cree First Nation v. Canada (Minister of Canadian Heritage)," 2005 SCC 69.

SCC (2014a), "Tsilhqot'in Nation v. British Columbia," 2014 SCC 44.

SCC (2014b), "Grassy Narrows First Nation v. Ontario (Natural Resources)," 2014 SCC 48.

Squamish Nation Chiefs and Council (2016), "Squamish Nation FortisBC environmental assessment agreement bulletin," accessed 22 September 2016 at http://www.squamish.net/ wp-content/uploads/2016/06/Membership-Bulletin-Fortis-EA-Agreement_JAK_01237855. pdf.

Stantec Consulting Ltd. (2014), "Progress Proposed Town North Gas Project. Project Description Under the British Columbia Environmental Assessment Act," accessed 21 September 2016 at http://a100.gov.bc.ca/appsdata/epic/html/deploy/epic_project_home_42 8.html.

Statistics Canada (2013), "Statistics Canada: 2011 national household survey Aboriginal population profile," accessed 7 November 2016 at http://www12.statcan.gc.ca/nhs-enm/20 11/dp-pd/aprof/index.cfm?Lang=E.

Tsilhqot'in National Government (2014), "Summary of the Tsilhqot'in Aboriginal title case (William Case) decision," accessed 11 October 2016 at http://www.tsilhqotin.ca/PDFs/20 14_07_03_Summary_SCC_Decision.pdf.

UBC First Nations and Indigenous Studies (2009), "Royal Proclamation, 1763," accessed 12 October 2016 at http://indigenousfoundations.arts.ubc.ca/home/government-policy/ royal-proclamation-1763.html.

WCC LNG Project Ltd. (2016), "Application information requirements for the WCC LNG Project," accessed 27 September 2016 at http://a100.gov.bc.ca/appsdata/epic/html/deploy/ epic_project_home_429.html.

WesPac Midstream (2016), "Valued component selection document for the WesPac Tilbury Marine Jetty Project,” accessed 27 September 2016 at http://a100.gov.bc.ca/appsdata/epic/ html/deploy/epic_project_home_435.html.

Woodfibre LNG (2016), "Squamish Nation reaches environmental assessment agreement with FortisBC on Eagle Mountain - Woodfibre Gas Pipeline Project," Woodfibre LNG. June 27, accessed 22 September 2016 at http://www.woodfibrelng.ca/squamish-nation-reachesenvironmental-assessment-agreement-with-fortisbc-on-eagle-mountain-woodfibre-gaspipeline-project/.

Woodside Energy Holdings Pty Ltd. (2016), "Application information requirements for the Grassy Point LNG Project," accessed 27 September 2016 at http://a100.gov.bc.ca/ appsdata/epic/html/deploy/epic_project_home_422.html.

WWF-Canada and UNBC-CIRC (2015), "Cumulative effects assessment and management: Sharing knowledge and building capacity in the North Coast (Workshop Summary Report)," accessed 18 October 2016 at http://awsassets.wwf.ca/downloads/cumulative effects_assessment_and_management__sharing_knowledge_and_building_capacit_2. pdf. 